\title{
COMPUTED TOMOGRAPHY SCANNING AS A TOOL FOR LINKING THE SKELETAL AND OTOLITH-BASED FOSSIL RECORDS OF TELEOST FISHES
}

\author{
by WERNER SCHWARZHANS ${ }^{1}$, HERMIONE T. BECKETT ${ }^{2}$ iD, JASON D. \\ SCHEIN $^{3}$ and MATT FRIEDMAN ${ }^{2,4}$ \\ ${ }^{1}$ Zoological Museum, Natural History Museum of Denmark, Copenhagen, Denmark; wwschwarz@aol.com \\ ${ }^{2}$ Department of Earth Sciences, University of Oxford, Oxford, UK; hermione.beckett@earth.ox.ac.uk \\ ${ }^{3}$ Bighorn Basin Paleontological Institute, Willow Grove, PA USA; jschein@bbpaleo.org \\ ${ }^{4}$ Department of Earth \& Environmental Sciences, \& Museum of Paleontology, University of Michigan, Ann Arbor, MI USA; mfriedm@umich.edu
}

Typescript received 11 August 2017; accepted in revised form 27 November 2017

Abstract: Micro-computed tomography $(\mu \mathrm{CT})$ scanning now represents a standard tool for non-destructive study of internal or concealed structure in fossils. Here we report on otoliths found in situ during routine $\mu \mathrm{CT}$ scanning of threedimensionally preserved skulls of Palaeogene and Cretaceous fishes. Comparisons are made with isolated otolith-based taxa to attempt correlations between the body fossil and otolith fossil records. In situ otoliths previously extracted mechanically from specimens of Apogon macrolepis and Dentex laekeniensis match our $\mu \mathrm{CT}$ models. In some cases, we find a high degree of congruence between previously independent taxonomic placements for otolith and skeletal remains (Rhinocephalus, Osmeroides, Hoplopteryx). Unexpectedly, in situ otoliths of the aulopiform Apateodus match isolated otoliths of Late Cretaceous age previously interpreted as belonging to gempylids, a group of percomorph fishes that do not appear in the body fossil record until the Palaeogene. This striking example of convergence suggests constraints on otolith geometry in pelagic predators. The otoliths of Apateodus show a primitive geometry for aulopiforms and lack the derived features of Alepisauroidea, the lizardfish clade to which the genus is often attributed. In situ otoliths of Early Cretaceous fishes (Apsopelix and an unidentified taxon) are not well preserved, and we are unable to identify clear correlations with isolated otolith morphologies. We conclude that the preservation of otoliths suitable for $\mu \mathrm{CT}$ scanning appears to be intimately connected with the taphonomic history, lithological characteristics of surrounding matrix, and syn- and postdepositional diagenetic effects.

Key words: Teleostei, $\mu \mathrm{CT}$ scanning, otolith, Apateodus, Osmeroides, Rhinocephalus.
Wiтн a diversity of species challenging that of all tetrapod radiations combined, teleost fishes are critical component of modern vertebrate biodiversity. Extant teleosts occupy aquatic settings ranging from ocean trenches to alpine streams, and show a striking range of anatomical innovations reflecting a broad range of ecologies (Nelson et al. 2016). Diversity in the modern fauna is complemented by a rich fossil record, which, for the teleost total-group, is well established since the Early Jurassic and extends deep into the Triassic (Friedman 2015; Tintori et al. 2015).

Teleosts, and indeed fishes generally, are unusual among vertebrates in having a fossil record characterized by a relative abundance of articulated, effectively complete skeletons. The bulk of our understanding of the relationships and diversification of extinct fishes, from the seminal work of Agassiz (1833-1844) onward, derives from this remarkable anatomical archive. Such intact fossils can yield osteological data comparable to that available for extant species, and can be critical for illuminating patterns of character evolution (Friedman 2008) or resolving phylogenetic relationships (Grande 2010). Articulated specimens also provide the substrate for functional and palaeobiological analysis, ranging from individual anatomical systems (e.g. jaws: Bellwood et al. 2015) to overall geometry of the body and fins (e.g. Friedman 2010). Despite these clear strengths, the body fossil record of teleosts suffers from conspicuous deficiencies. The preservation of articulated fishes requires particular taphonomic conditions, with horizons yielding complete skeletons generally restricted to specific facies such as laminated limestones and anoxic shales. The result is a highly heterogenous, gap-filled stratigraphic distribution of exceptional deposits (e.g. apparent abundance during 
sea-level highstands: Guinot \& Cavin 2015) that, combined with the less informative nature of isolated fish bones, has led to repeated suggestions that the fish fossil record is particularly prone to bias arising from so-called Lagerstätten effects (Patterson \& Smith 1987, 1989; Patterson 1993a, b; but see Lloyd \& Friedman 2013).

Skeletal fossils are not the only palaeontological line of evidence bearing on past patterns of fish diversity; they are joined by a rich record of isolated otoliths. Informally known as 'ear stones', otoliths are consolidated aragonitic bodies housed within the labyrinth organ of fishes, and are involved in hearing and balance. Living actinopterygians have three pairs of otoliths, with the largest typically located in the sacculus. First systematically described by Koken (1884), otoliths are often diagnostic for species, genera and higher taxa. They are abundant in the fossil record where aragonite is preserved and sediments are unconsolidated. The otolith record is, as a consequence, denser both stratigraphically and geographically than the spottier archive of skeletal remains. The ubiquity of fossil otoliths led Patterson (1977, p. 580) to conclude that the fossil records of teleosts and mammals were comparable in terms of quality and density: 'whereas mammals have teeth, teleosts have otoliths'.

The otolith record is not without problems. Facies biases aside, otoliths are relatively uncommon in Mesozoic rocks, a probable consequence of 'calcite sea' chemistry that favoured the dissolution of aragonite during this interval (Nolf 1995; similar patterns apply to aragonitic fossils in other intervals characterized by comparable marine chemistry: Palmer et al. 1988; Cherns \& Wright 2000). Reports of Palaeozoic otoliths are sparse (Nolf 2013), reflecting little research effort and rarity of unconsolidated sediments of this age. These taphonomic and research biases are minor in comparison to the greatest challenge of isolated fossil otoliths: their allocation to genera is almost exclusively based on correlation with extant otoliths, rather than association with diagnostic fossil skeletal remains. This phenetic exercise becomes more problematic for otoliths from increasingly ancient strata. The taphocoenoses of otoliths and articulated skeletons diverge as a consequence of mineralogical differences, a restrictive range of sedimentary settings conducive to the preservation of articulated skeletons and otoliths, and difficulties in retrieving in situ otoliths from articulated skeletons. Because few otoliths are known in situ from body fossils, the taxonomy of fossil otoliths has developed largely parallel to that of articulated material. Patterson's claimed equivalence between mammal teeth and teleost otoliths is thus false. To put the teleost record in perspective, it is as if extinct mammals were known from abundant isolated teeth combined with rarer skeletons almost always lacking preserved dentition.

The identification and characterization of otoliths preserved in association with skeletons provides the key to marrying these two complementary teleost fossil records. The most recent census suggests that fewer than 100 skeleton-based fossil species bear otoliths (Nolf 2013). In many of these taxa otoliths are mentioned rather than described in detail (but see: Fedotov 1976; Schwarzhans 2014; Prikryl et al. 2017; Schwarzhans et al. $2017 a-e)$, and most of those in situ finds are from Oligocene or younger deposits. So far few are recorded from the Eocene, and none from the Paleocene and Late Cretaceous (Fig. 1). The Late Cretaceous-Palaeogene represents a crucial interval in the evolution of modern teleosts, associated with the origin of many extant lineages, especially within the species-rich percomorph radiation (Near et al. 2013). In addition, multiple skeleton-based lineages of teleost fishes became extinct at or near the Cretaceous-Palaeogene boundary (Friedman 2009). Otoliths are virtually unknown for these once abundant extinct groups, posing a substantial problem for the interpretation of isolated otoliths from the Cretaceous.

Heavily compressed skeletons are the most common articulated remains in the fish record, and it is from such specimens that the vast majority of in situ otoliths have been described. However, the geometry of such specimens is often a challenge for standard tomographic studies (although laminography might represent a productive alternative in the future: Sutton 2008). There are a handful of cases of otoliths reported from three-dimensionally preserved fish fossils (e.g. the Eocene ophidiiform Ampheristus: Stinton 1966; Schwarzhans 2007a), and while three-dimensional preservation is often associated with famous Lagerstätten (Maisey 1991; Long \& Trinajstic 2010), horizons yielding fully inflated fish crania are distributed throughout the nearly 450 million year fossil history of jawed vertebrates (e.g. Zhu et al. 2013; Friedman \& Giles 2016). Here we report on the efficacy of highresolution micro-computed tomography $(\mu \mathrm{CT})$ scanning for isolating otoliths from three-dimensionally preserved fossil fish crania. Our survey focuses on the CretaceousEocene interval, and examines material from a variety of host lithologies including sands, chalks and clays. Although the quality of preservation varies considerably between specimens, sufficient detail is provided to allow us to make comparisons with previously described otoliths and to test their past taxonomic assignment using characters preserved in the host crania.

\section{MATERIAL AND METHOD}

\section{Tomographic procedures}

In situ otoliths described here were incidental discoveries made as part of a broader initiative to study three- 


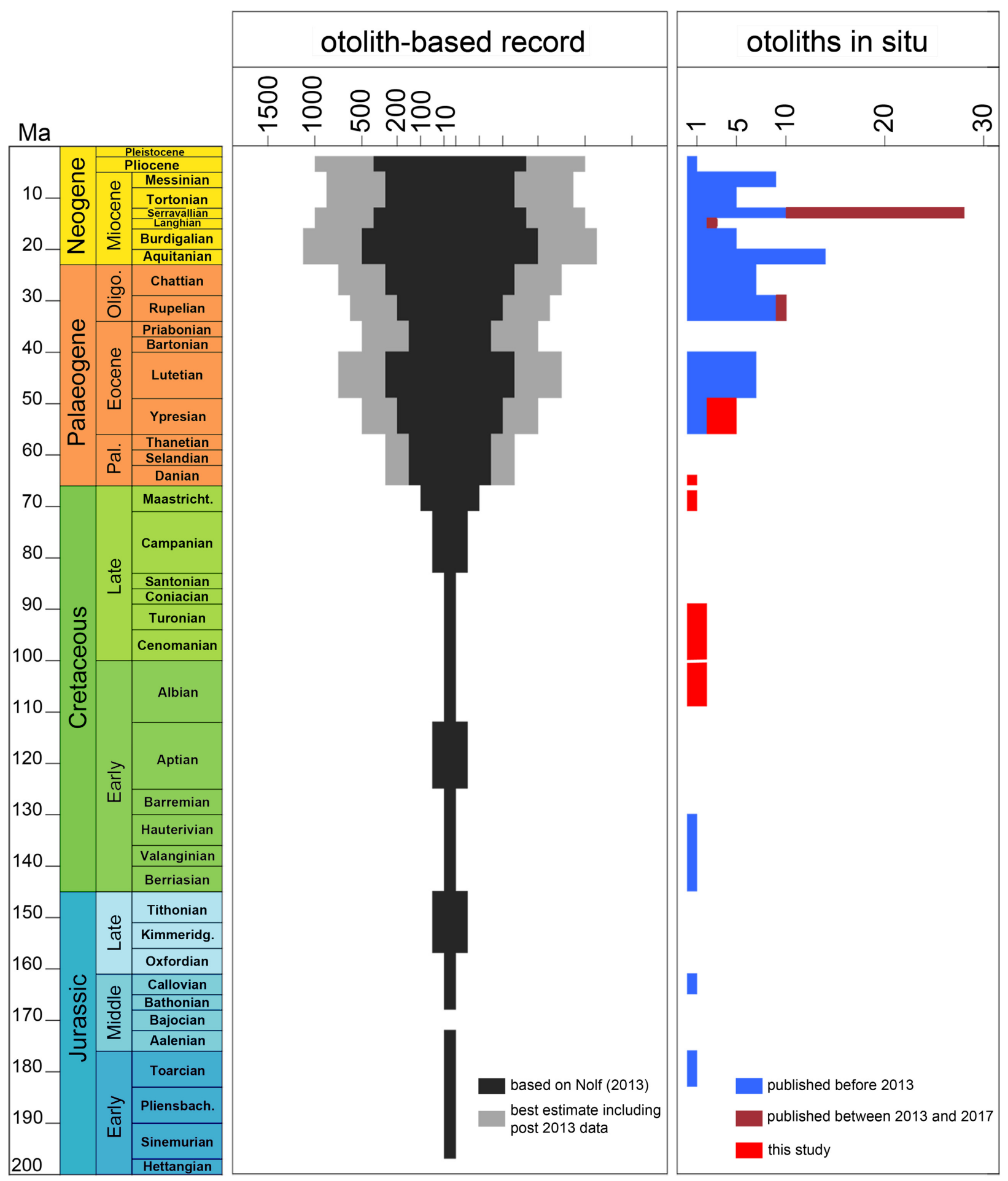

FIG. 1. Patterns of teleost diversity from the Jurassic to the present as gauged from the otolith fossil records.

dimensional fossil fish crania of Cretaceous-Palaeogene age, emphasizing material from the English Chalk Group and London Clay Formation but considering other deposits with similar modes of preservation (e.g. Beckett \& Friedman 2016; Close et al. 2016; Friedman et al. 2016;
Beckett et al. 2017). The specimens were scanned with a Metris X-Tek HMX ST CT scanner in the Imaging and Analysis Centre of the Natural History Museum, London. The scan parameters (filters, beam intensity and beam energy) are given in Table 1 and Schwarzhans et al. (2018). 


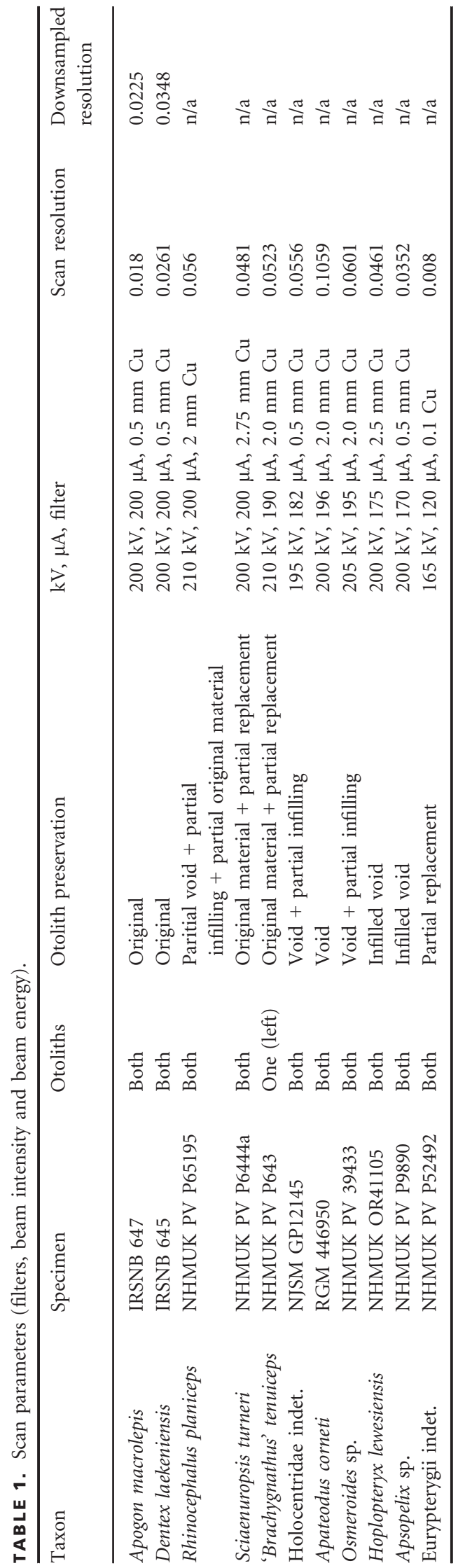

Tomogram stacks were segmented using Mimics Materialise v.16.0-18.0 x64 (http://biomedical.materialise.com/ mimics). Renderings of resulting models were created using Blender (http://www.blender.org). Figure 2 shows an example of a CT scan of a head of the Eocene apogonid Apogon macrolepis Storms, 1896 with the position of the otoliths inside the otic capsule highlighted. Photographs of specimens for which we report in situ otoliths in this paper are shown in Figure 3. Following best practice in studies of digital morphology (Davies et al. 2017), source files are available for download from Schwarzhans et al. (2018).

\section{Abbreviations}

Institutional. BMNH, The Natural History Museum, Life Sciences, London, UK (see also NHMUK for materials housed in the Earth Sciences division); FBH, Fischerrei-Biologie Hamburg, Germany (now ZMH); IRSNB, Royal Belgian Institute of Natural Sciences, Brussels, Belgium; LACM, Los Angeles County Museum of Natural History, Los Angeles, California, USA; MNHN, Museum national d'Histoire naturelle, Paris, France; NHMUK, The Natural History Museum, Earth Sciences, London, UK (see also BMNH); NJSM, New Jersey State Museum, Trenton, New Jersey, USA; NSMT, National Science Museum, Department of Zoology, Tokyo, Japan; RGM, Naturalis Biodiversity Center, Leiden, The Netherlands; SMF, Natur-Museum und Forschungsinstitut Senckenberg, Frankfurt am Main, Germany; WAM, Western Australian Museum, Perth, Western Australia, Australia; ZMH, Universität Hamburg, Zoologisches Institut und Museum, Hamburg, Germany; ZMUC, Københavns Universitets Zoologisk Museum, Copenhagen, Denmark.

Anatomical. CaL, cauda length; OH, otolith height; OL, otolith length; OsL, ostium length; OT, otolith thickness.

\section{RESULTS}

There are strong geological influences on the relative preservation of otoliths (Nolf 1995, 2013). Consequently, we dedicate the following section to the depositional context for the in situ otoliths described later in the Systematic Palaeontology section. Geological details are presented in the sequence of the respective units yielding our fossil specimens.

\section{Palaeogene}

The early Palaeogene is an important interval in the history of fish evolution, marked by the first appearance of many modern teleost families. This pattern is reflected by both skeleton and otolith-based datasets (Patterson $1993 a, b)$. However, these two archives show little 

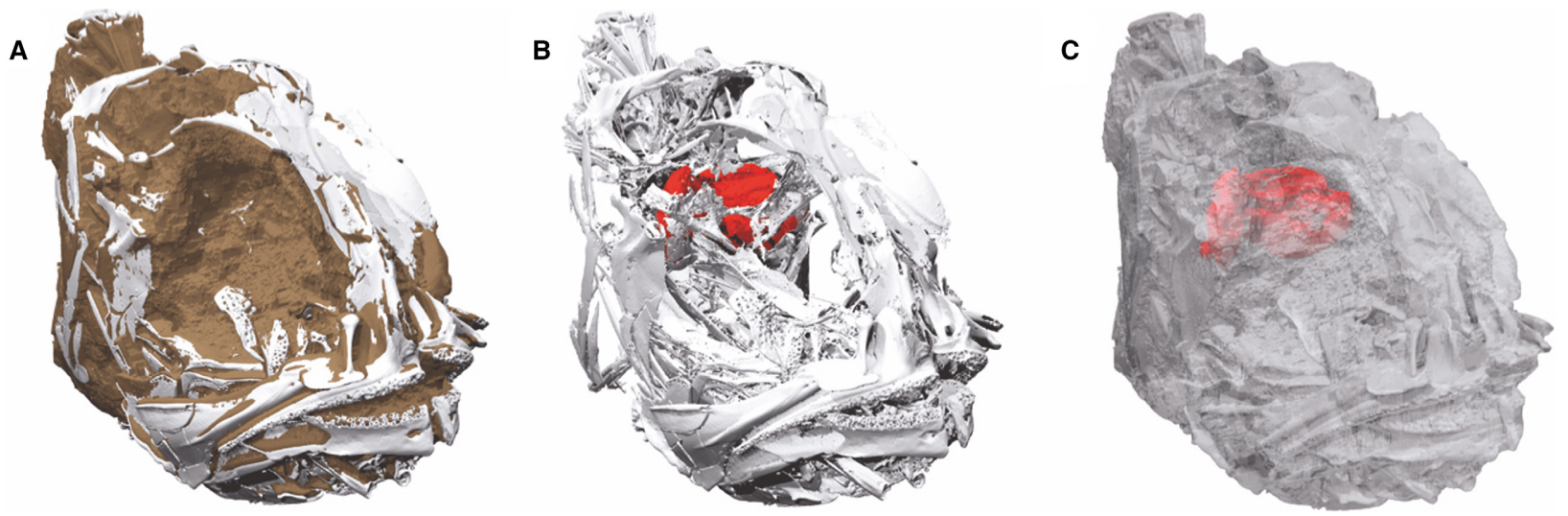

FIG. 2. Models of the Eocene cardinalfish Apogon macrolepis based on $\mu \mathrm{CT}$ and highlighting the encased otolith. A, model of skull and encasing matrix. B, model of fossil only with matrix remove, bone opaque and otoliths shown in red. C, model of fossil only with matrix removed, bone rendered semitransparent and otoliths shown in red.

overlap: only 10 skeleton-based species are known with in situ otoliths from the Paleocene and Eocene (Nolf 2013; this study), despite the exceptional fish Lagerstätten known from this interval (Fig. 1; Patterson 1993a; Friedman et al. 2016). Here we are able to corroborate three previous reports of in situ otoliths obtained via breakage or potentially damaging mechanical preparation for the late Eocene (Bartonian) Wemmel Sands Member of the Maldegem Formation of Belgium (the apogonid Apogon and sparid Dentex). To these we add several novel examples, all from the early Eocene (Ypresian) London Clay Formation of the UK: the incertae sedis acanthomorphs 'Brachygnathus' and Sciaenuropsis, and the gadiform Rhinocephalus. We also report in situ otoliths from an undescribed holocentroid from the earliest Paleocene (Danian) or latest Late Cretaceous (Maastrichtian) Hornerstown Formation of New Jersey, USA.

Wemmel Sands Member, Maldegem Formation, Belgium. The Wemmel Sands Member crops out around Asse and Wemmel, north-west of Brussels, Belgium. Lithologically, it is composed of grey, glauconitic sands with an increasing clay component toward the top. The member can reach $10 \mathrm{~m}$ in thickness, but averages 4$5 \mathrm{~m}$. It is classically assigned to the regional Wemmelian stage, which corresponds to the Bartonian stage of the international timescale (De Geyter et al. 2006). It yields a modest fauna of teleosts known from skeletal remains: an ophichthyid eel, a sparid, an apogonid and a putative serranid (but see below; Storms 1896). We examined the type material of the final two taxa.

\section{London Clay Formation, UK}

The London Clay Formation is $90-130 \mathrm{~m}$ thick sequence of argillaceous to slightly calcareous marine clays of early
Ypresian age. The best known outcrops are found in southern England, although deposits in continental Europe correlative with the London Clay Formation are known from Holland, Denmark, Germany and France, with extensive exposures of the Belgian Kortrijk Clay Formation (Friedman et al. 2016). Fossil fishes occur in calcareous concretions that formed around the decaying fossil during an early diagenetic phase shortly after deposition, resulting in common three-dimensional preservation. Exposures on the Isle of Sheppey have yielded most articulated fish crania from the London Clay Formation (Casier 1966). A majority of historical specimens derive from this locality, with continued collecting yielding new material (Clouter et al. 2000; Rayner et al. 2009). The depositional setting for the London Clay Formation on the Isle of Sheppey is interpreted as being $80 \mathrm{~km}$ from the shoreline (Collinson 1983).

Hornerstown Formation, New Jersey, USA. The Hornerstown Formation is a $3 \mathrm{~m}$ thick unit of bioturbated, green glauconitic sands, deposited in a marine setting (Sugarman et al. 1995). It includes a main fossil-bearing layer roughly $10 \mathrm{~cm}$ thick and only a few centimetres above the contact with the Cretaceous (Maastrichtian) Navesink Formation. It contains Late Cretaceous faunal elements, including ammonites and mosasaurs, and is regarded either as a lag deposit reworking underlying fossils (Kennedy \& Cobban 1996) or a condensed section (Staron et al. 2001). This layer also contains delicate and semi-articulated fossils (including the fishes described below) that seem unlikely to have been reworked. Above this fossil-bearing layer, the Hornerstown Formation is early Paleocene (Danian) in age based on microfossil biostratigraphy (Koch \& Olsson 1977). The age of the fossil-bearing layer remains ambiguous, and we treat it here as latest Maastrichtian or earliest Danian. 


\section{Cretaceous}

The Late Cretaceous was a time of high global sea levels, and is characterized by a rich body fossil record of fishes (Patterson 1993a, b; Friedman et al. 2016). Marine faunas of this age consist of a variety of members of extant clades, including elopomorphs, aulopiforms, and earlydiverging acanthomorph groups (e.g. lampridiforms, trachichthyoids). These are joined by extinct groups, including a range of stem teleost clades like ichthyodectiforms and pachycormids, as well as late-surviving marine holosteans. Late Cretaceous otoliths are less common and more poorly known than those from younger strata. In particular, the correspondence of otoliths of this age to those of modern fishes is less clear than for Cenozoic examples. Consequently, there is debate about the interpretation of some Late Cretaceous otoliths and whether or not they represent crown percomorphs (Nolf \& Stringer 1996; Schwarzhans 2010, 2012; Nolf 2013, 2016), a group represented in rocks of this age by a handful of

A
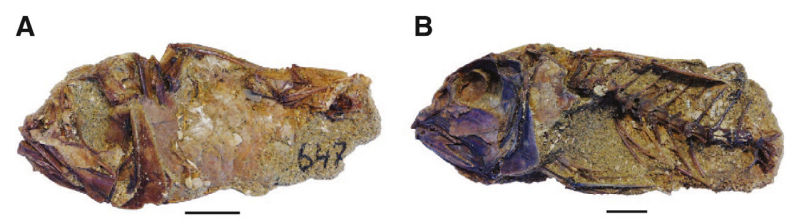

C

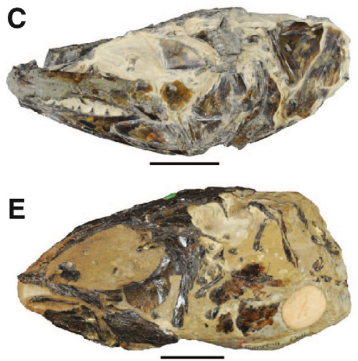

$\mathbf{F}$
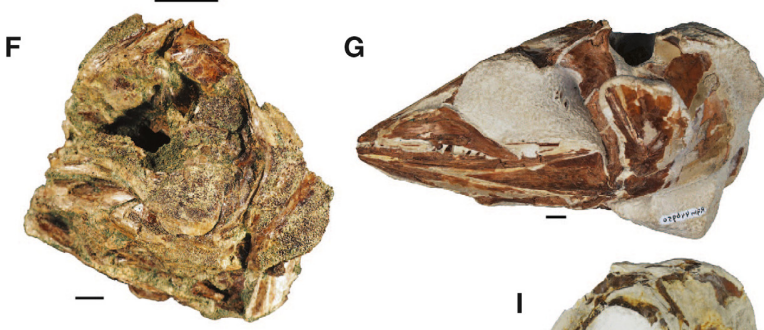

H

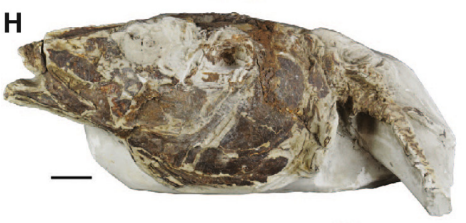

$\mathbf{J}$

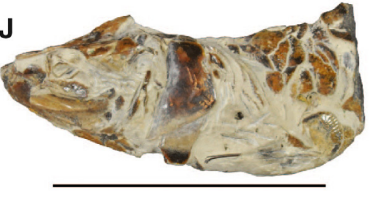

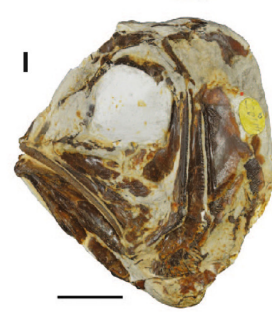

D
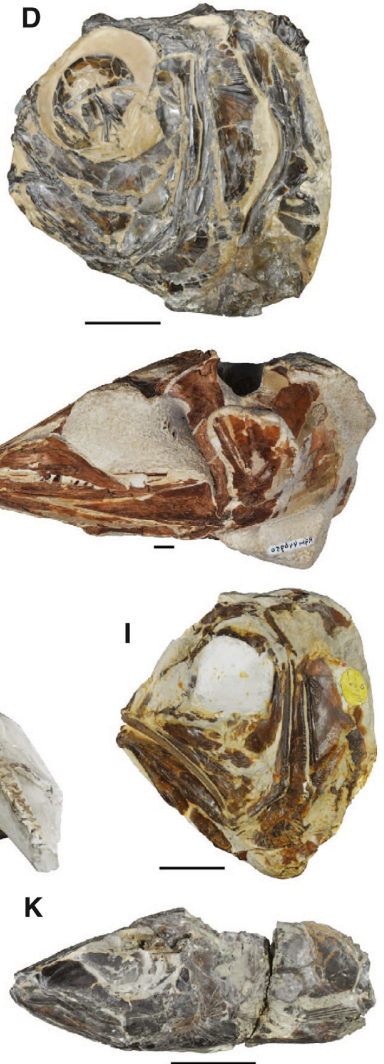

body fossils (e.g. Carnevale \& Johnson 2015). The record of Early Cretaceous marine fishes is poor relative to that of the Late Cretaceous, with the most diverse assemblages from late in the Early Cretaceous: the Aptian Gault Clay Formation of the UK (Forey \& Longbottom 2010), Toolebuc Formation of Australia (Clode 2015) and Tlayúa Formation of Mexico (Applegate 1996). The best-studied fish faunas in earlier parts of the Early Cretaceous derive overwhelmingly from continental settings, including the Wealden of the UK and Belgium (Traquair 1911; Woodward 1916, 1918, 1919), and exceptional lacustrine Lagerstätten in Spain (Poyato-Ariza \& Martín-Abad 2016) and China (Chang \& Jin 1996).

We report in situ otoliths of Late Cretaceous age for three taxa from two deposits: the aulopiform Apateodus corneti, from the Maastricht Formation of the Netherlands; and the albuloid Osmeroides sp. and trachichthyoid Hoplopteryx lewesiensis from the English Chalk Group of the UK. All three derive from chalks, with the otoliths themselves preserved either as a void following the dissolution of the original aragonite (Apateodus) or as a partial (Osmeroides) or complete (Hoplopteryx) infilling of such a void. Early Cretaceous examples are from the Gault Clay Formation of the UK, and include a possible eurypterygian and the crossognathiform Apsopelix anglicus. Isolated otoliths from this deposit are often preserved in primary aragonite, but in situ otoliths appear to have been replaced and overgrown with a dense mineral. This is

FIG. 3. Photographs of fossil fish skulls studied using $\mu \mathrm{CT}$ scanning to examine in situ otoliths. A, Apogon macrolepis IRSNB 647 (cotype), Eocene (Bartonian), Wemmel Sands Member, Maldegem Formation, Belgium. B, Dentex laekeniensis IRSNB 645 (holotype of Plesioserranus wemmeliensis), Wemmel Sands Member, Maldegem Formation, Belgium. C, Rhinocephalus planiceps NHMUK PV P65195, Eocene (Ypresian), London Clay Formation, UK. D, Sciaenuropsis lerichei NHMUK PV P6444a (holotype of Sciaenuropsis turneri), Eocene (Ypresian), London Clay Formation, UK. E, 'Brachygnathus' tenuiceps NHMUK PV P643, Eocene (Ypresian), London Clay Formation, UK. F, Holocentridae indet. NJSM GP12145, Late Cretaceous - Paleocene (Maastrichtian-Danian), Hornerstown Formation, New Jersey, USA (photograph by D. Davense, University of Oxford). G, Apateodus corneti RGM 446950, Late Cretaceous (Maastrichtian), Maastricht Formation, the Netherlands (specimen image reversed). H, Osmeroides sp. NHMUK PV 39433, Late Cretaceous (probably Cenomanian), English Chalk Group, UK (specimen image reversed). I, Hoplopteryx lewesiensis NHMUK OR41105, Late Cretaceous (Cenomanian), Grey Chalk Group, UK. J, Apsopelix anglicus NHMUK PV P9890, Early Cretaceous (Albian), Gault Clay Formation, UK. K, ?Eurypterygii indet. NHMUK PV P52492, Early Cretaceous (Albian), Gault Clay Formation, UK. All scale bars represent $10 \mathrm{~mm}$. Colour online. 
probably pyrite, which is visible externally on some fish remains from the Gault Clay Formation.

Maastricht Formation, the Netherlands. The specimen of Apateodus described here was collected near Valkenburg aan de Guel, a village to the east of Maastricht, the Netherlands (Kruizinga 1924). Here, classic members of the Maastricht Formation interdigitate with the Kunrade Limestone facies (J. Jagt, pers. comm., December 2016). These deposits are shallow marine in origin (Schiøler et al. 1997; Vandenberghe et al. 2004), and are constrained to the late Maastrichtian on the basis of cephalopod biostratigraphy (Jagt \& Jagt-Yazykova 2012). Although some articulated fish remains are known from these Maastrichtian deposits in the southern Netherlands (Kruizinga 1924; Friedman 2012), they are rare, with most material consisting of isolated fragments. Threedimensionally preserved material includes the skulls of Apateodus (Kruizinga 1924; Friedman 2012), as well as a cranium of Enchodus that was acid prepared (Goody 1969), obliterating any possible evidence of in situ otoliths. We did not detect any otoliths in a $\mu \mathrm{CT}$ scan of a large specimen of Hoplopteryx from the roughly coeval Ciply-Malogne Phosphatic Chalk of Belgium (Friedman 2012, fig. 8B).

\section{English Chalk Group, UK}

The English Chalk Group is divided into the Grey Chalk and White Chalk subgroups (Gale \& Kennedy 2002). It spans much of the Late Cretaceous, and although fossils are found throughout, articulated fishes are largely restricted to the Cenomanian and Turonian parts of the succession (Friedman et al. 2016). The best fish fossils from these deposits were collected when chalk pits were worked by hand, and the stratigraphic control on these old specimens is often poor (Patterson 1964; Longbottom \& Patterson 2002; e.g. Osmeroides below). It is therefore impossible at present to determine which levels within the English Chalk Group might be most conducive to the preservation of otoliths. In any case, in situ otoliths are dissolved in these rocks and the voids often infilled by secondary mineralization. The dissolution of aragonite in the Chalk succession is well documented, with aragonitebiomineralizing taxa becoming increasingly uncommon finds upsection (Gale \& Kennedy 2002). Out of over nearly 30 genera of fishes scanned from the Chalk, we have only recognized two reasonably well-preserved examples described below, plus an additional specimen of Trachichthyoides (NHMUK PV OR39076) with fragments of otoliths that are too poorly preserved to describe in any detail.

\section{Gault Clay Formation}

The Gault Clay Formation of the UK underlies the English Chalk Group and comprises a 20-50 m sequence of dark clay deposited in an open marine setting (Gale \& Owen 2010). The Gault Clay Formation is middle to late Albian in age and shares many bony fish genera in common with the Chalk. Articulated fish remains from the Gault are rare and are often pyritized to some degree (Forey \& Longbottom 2010). In addition to skeletal remains, isolated otoliths in their original aragonitic composition are known from this deposit (Stinton 1973), representing a modest fauna of three species recognized as valid by Nolf (2010). None of these otoliths known from isolated remains appear to match the in situ examples described below.

\section{DISCUSSION AND CONCLUSIONS}

Preservation of in situ otoliths as a function of depositional setting and diagenesis: a prospectus for future studies

Our survey of three-dimensionally preserved fossil fish skulls sampled a variety of lithologies, all representing marine depositional environments: chalks (English Chalk Group, Maastricht Formation), clays or marls (Gault Clay Formation), phosphatic or carbonate concretions (London Clay Formation) and sandstones (Hornerstown Formation, Wemmel Sands Member). While otoliths can be preserved in all of these settings, it is clear (as in the case of isolated otoliths) that some lithologies and diagenetic histories are more conducive to the preservation and recovery of in situ examples in three-dimensionally preserved specimens. Glauconitic sands appear to hold high potential for preservation of in situ otoliths, in terms of the percentage of specimens yielding otoliths as well as the anatomical fidelity of those examples, although we acknowledge the limited sample size of our surveys. All specimens studied from the Hornerstown Formation (Maastrichtian to Danian) and Wemmel Sands Member (Bartonian) yield intact otoliths showing fine anatomical details which are directly comparable to modern examples. However, the modes of preservation in these units is distinctly different, with otoliths from the Wemmel Sands Member being original aragonitic material (as shown from physically extracted specimens) and those from the Hornerstown Formation preserved as partially infilled void spaces. Indeed, our scans of the otoliths of Apogon macrolepis and Dentex laekeniensis provide clear evidence that our non-invasive approach yields anatomical detail comparable to physical in situ otolith finds previously reported for these species (Taverne \& Nolf 1979; Nolf 2013). 
Clays and marls are more variable in their preservation of otoliths. Both the London Clay Formation (Ypresian) and Gault Clay Formation (Albian) yield three-dimensional skulls with in situ otoliths, but there are differences in the nature and frequency of preservation. Both Gault specimens examined show in situ otoliths, but in both cases they have been subject to partial dissolution and replacement/overgrowth with a dense mineral, probably pyrite. Paradoxically, the Gault Clay Formation is also known for superb preservation of isolated otoliths in original aragonite material (Stinton 1973; Nolf 2010). In cases where otoliths are not partially replaced, they might be difficult to distinguish from surrounding clay matrix using $\mu \mathrm{CT}$. Study of a fish skeleton from an unconsolidated marl from the Miocene of New Zealand revealed no otolith in tomograms, while a perfectly preserved example in original aragonitic composition was retrieved during physical preparation (Schwarzhans et al. 2012). Unfortunately, clays and marls are well-suited for preservation of aragonite, and mechanical extraction of otoliths might be necessary in cases where $\mu \mathrm{CT}$ scanning provides insufficient contrast.

Visible otoliths are much rarer in the concretions bearing fishes from the London Clay, although they can be better preserved than examples from the Gault Clay. We have scanned three-dimensionally preserved skulls of over 42 genera of London Clay fishes, from which we were able to identify in situ otoliths in the three taxa described in this paper plus Ampheristus (NHMUK PV P4540e; not described here), a genus for which in situ otoliths has been reported in the past through physical exposure (Casier 1966; Stinton 1966). Modes of preservation range from apparently unmodified ('Brachygnathus') to completely or partially replaced by probable pyrite (Rhinocephalus, Sciaenuropsis). The relative rarity of in situ otoliths in the London Clay is probably a joint function of taphonomy, diagenesis and taxonomy. The specimen of Rhinocephalus reported here is the only individual of the genus that we have examined with $\mu \mathrm{CT}$ that bears in situ otoliths, strongly implicating individual taphonomic and diagenetic histories (and specific geological horizons) as being significant in the preservation of these structures. With respect to taxonomy, scombroid or scombroid-like fishes make up a substantial fraction of well-preserved London Clay fishes, both in terms of taxonomic diversity and absolute abundance (Monsch 2005; Friedman et al. 2016). Otoliths of modern scombroids are small and delicate, suggesting that their retrieval in $\mu \mathrm{CT}$ scans is unlikely even in ideal cases. We have not detected any otoliths in the numerous scombroids scanned from the London Clay Formation (e.g. Beckett \& Friedman 2016).

Chalks appear to very rarely yield otoliths in an unaltered state. The only records of isolated otoliths from such lithologies derived from the 'næse' chalk of Faxe, Denmark, where they are recrystallized in calcite (Schwarzhans 2003). As a general rule most or all aragonitic matter, including otoliths, is dissolved in chalk. Where in situ otoliths were found in the $\mu \mathrm{CT}$ scans, they are either preserved as voids (Apateodus) or voids infilled in part or whole by secondary mineralization (Hoplopteryx, Osmeroides). We only scanned one specimen from the Maastricht Formation, so cannot comment on the relative rarity of in situ otoliths from that deposit. However, we have examined nearly 30 genera from the English Chalk Group using $\mu \mathrm{CT}$ and have found only the two examples described here plus remains in the trachichthyoid Trachichthyoides that are too poorly preserved to describe (NHMUK PV OR39076). Preservation of otolith voids in such deposits therefore seems to depend primarily on diagenetic alterations after dissolution of the aragonitic otolith. When preserved as a void in a finegrained matrix, $\mu \mathrm{CT}$ results can be excellent, as in Apateodus. However, infilling and subsequent growth of diagenetic minerals can substantially disrupt preserved structure and result in lower fidelity models as appears to be the case in Hoplopteryx.

Collectively, these results suggest particular depositional settings and diagenetic events likely and unlikely to yield otoliths. Three-dimensional skulls from marine sandstones appear to have considerable potential for preserving in situ otoliths, but intact fossils in such deposits are relatively rare. As possible examples for further investigation, we note a three-dimensionally preserved 'elopid' from the Codell Member of the Late Cretaceous (Turonian) Carslile Formation of Kansas (Miller 1958) and the intact skull of the trachichthyoid Antarctiberyx from the Late Cretaceous Lopez de Bertodano Formation (Campanian-Maastrichtian) of Seymour Island, Antarctica (Grande \& Chatterjee 1987).

Several marine clays yield three-dimensionally preserved fish material, mostly in calcareous concretions, with potential to preserve otoliths in situ: the early Oligocene (Rupelian) Boom Clay formation of Belgium (Taverne et al. 2006), the middle Eocene (Lutetian) Lillebælt Clay Formation of Denmark (Schwarzhans 2007a), the early Eocene (Ypresian) Kortrijk Clay Formation of Belgium (Casier 1946, 1966) and the Early Cretaceous (Albian) deposits of Aube, France (Wenz 1965). Schwarzhans (2007a) described in situ otoliths from the Lillebælt Clay, but $\mu \mathrm{CT}$ investigation of other specimens have thus far not yielded any additional examples, perhaps reflecting minimal differences in X-ray attenuation between aragonitic otoliths and the surrounding matrix. We have also made preliminary investigations of specimens from the Kortrijk Clay Formation of Belgium and Albian of Aube, France, with contrasting results. None of the samples examined to date from the Kortrijk Clay Formation preserve otoliths. However, the similarity of fossil preservation between the London Clay Formation 
and its equivalent the Kortrijk Clay Formation leads us to believe that otoliths might be present in some specimens from the latter, but that these might be comparatively rare, as they are in the British deposit. By contrast, the single specimen of the megalopid Elopoides from Aube (MNHN CTE 14) shows otolith-like structures in its saccular chambers, although the resolution of our data was insufficient to yield interpretable results. We therefore view fossils from this site as being particularly promising for in situ otoliths and note that well-preserved material of Apsopelix from Aube (Wenz 1965) could help to constrain our poor models of otoliths in this genus from the approximately coeval Gault Clay Formation. Although the Gault otoliths that we studied are limited in terms of detail, the apparently high yield of in situ otoliths suggests that additional remains from this deposit should be targeted by future studies. Particularly significant would be examples of in situ otoliths from extinct teleost groups such as pachyrhizodontids and ichthyodectiforms, both of which are known from the Gault Clay Formation (Forey \& Longbottom 2010).

Although they are a common matrix for three-dimensionally preserved fish skulls, chalks and other carbonates are promising candidates for the recovery of in situ otoliths only when no destructive mineralization or other diagenetic effects followed the ubiquitous dissolution of the aragonitic otoliths. This is exacerbated by low or no density contrast between any preserved otolith material and the surrounding matrix. The highest potential for otolith preservation in such settings is as voids such as those seen in the Maastricht Formation, or with complete subsequent infillings like in the Cretaceous examples from the English Chalk Group. Thus, while abundant threedimensionally preserved or only slightly crushed remains of extinct groups (e.g. pycnodonts, pachycormids, crossognathiforms, ichthyodectiforms) are known from deposits not sampled in this study (e.g. Smoky Hill Member of the Niobrara Formation: Shimada \& Fielitz 2006), the strong bias against aragonitic fossils in such sites (Carpenter 2008) leads us to suspect that in situ otoliths will unfortunately be rare.

\section{$\mu C T$ and the potential for linking the otolith and body fossil records}

One of the most exciting prospects of the study of in situ otoliths is the reconciliation of the parallel systems of nomenclature. Here, we are able to correlate skeleton- and otolith-based taxonomies in several instances (Table 2). In terms of fossils of Palaeogene age, we find that in situ otoliths closely match the structure of isolated otoliths assigned to the same taxonomic groups. Indeed, the otoliths of the gadiform Rhinocephalus and the unnamed holocentrid from the Hornerstown Formation closely match what would be expected in such taxa, while the otoliths of the apogonid Apogon match previously described physical (rather than tomographically reconstructed) examples studied in situ. This broadly validates the approach used to identify isolated otoliths of this age, which show a reasonably close correspondence with those from extant fishes. However, it is apparent that the study of in situ otoliths is more than simply a corroborative exercise. In fact, several of the otoliths examined using $\mu \mathrm{CT}$ illuminate the taxonomic identities of the containing cranial skeletons, some of which have been the subject of remarkably little anatomical study and have been of ambiguous taxonomic placement. For example, we find that the putative serranid Plesioserranus wemmeliensis is a small specimen of the co-occurring sparid Dentex laekeniensis.

Our findings relating to Cretaceous otoliths are arguably more significant than those from the Palaeogene, despite representing a more limited taxonomic sample. Scant records of in situ otoliths from Mesozoic teleosts include Middle and Early Jurassic examples from Leptolepis cf. coryphaenoides (Bronn) (see Nolf 2013), Leptolepis normandicus Nybelin, 1962 (see Delsate, 1997), Cavenderichthys talbragarensis (Woodward 1895; WS \& M. Frese, in prep.) and one record from the freshwater Lycoptera middendorfi (Müller, 1848) from the Early Cretaceous of 'Transbaikalien' in Russia (Reis 1909). To this modest list we add a further five from the Cretaceous: Apsopelix anglicus (Dixon, 1850) (Cenomanian-Turonian), Osmeroides sp. (Cenomanian-Turonian), Apateodus corneti (Forir, 1887) (Maastrichtian), Hoplopteryx lewesiensis (Mantell, 1822) (Cenomanian-Turonian), and an undetermined form from the Gault Clay Formation (Albian). In the case of Osmeroides and Hoplopteryx, the taxonomic identifications of the otolith-based species show clear correspondance with skeleton-based taxonomy. This is not surprising, as both belong to groups persistent until today and from which many fossil otolith-based taxa are known more-or-less continuously since Late Cretaceous times. Apsopelix anglicus and Apateodus corneti belong to extinct clades: Apsopelix as a crossognathiform of debated position just outside or just within the teleost crown group, and Apateodus to the enigmatic aulopiform group Ichthyotringoidei (Fig. 4). While there is no clear correlation of in situ otoliths of Apsopelix with known otolith-based taxa, it does appear to show a generalized morphology broadly consistent with the inferred phylogenetic position of the crossognathiforms. Significantly, Apateodus does show a clear correlation with isolated Cretaceous otoliths previously attributed to Gempylidae, which is highly nested within acanthomorph phylogeny. Our re-identification of such otoliths as those of aulopiforms reconciles a conspicuous discrepancy between the otolith and body fossil record of gempylids, the first 
TA BLE 2. Correlations between isolated otolith and body fossil data following in situ otolith finds of this study.

\begin{tabular}{|c|c|c|c|}
\hline $\begin{array}{l}\text { Skeleton with } \\
\text { otoliths in situ }\end{array}$ & $\begin{array}{l}\text { Synonymized } \\
\text { otolith-based taxa }\end{array}$ & $\begin{array}{l}\text { Related and revised } \\
\text { otolith-based species }\end{array}$ & $\begin{array}{l}\text { Most recent previous allocation } \\
\text { of otolith-based species }\end{array}$ \\
\hline \multicolumn{4}{|l|}{ Eocene and Paleocene } \\
\hline \multicolumn{4}{|l|}{ Gadiformes } \\
\hline $\begin{array}{l}\text { Rhinocephalus planiceps } \\
\text { Casier, } 1966\end{array}$ & $\begin{array}{l}\text { Merluccius nodosus } \\
\text { Stinton, } 1977\end{array}$ & Rhinocephalus planiceps Casier, 1966 & Merluccius nodosus Stinton, 1977 \\
\hline \multicolumn{4}{|l|}{ Beryciformes } \\
\hline \multirow{3}{*}{$\begin{array}{l}\text { Sciaenuropsis turneri } \\
\text { Casier, } 1966 \\
\text { [syn. Sciaenuropsis } \\
\text { lerichei } \\
\text { (Schubert, 1916)] }\end{array}$} & $\begin{array}{l}\text { Monocentris? lerichei } \\
\text { Schubert, } 1916\end{array}$ & Sciaenuropsis lerichei (Schubert, 1916) & $\begin{array}{l}\text { 'Priacanthida' lerichei } \\
\text { (Schubert, 1916) [Nolf, 2013] }\end{array}$ \\
\hline & Beryx nova Stinton, 1978 & Sciaenuropsis bella (Stinton, 1980) & Pristigenys bella Stinton, 1980 \\
\hline & & Sciaenuropsis selsiensis (Stinton, 1978) & $\begin{array}{l}\text { 'Priacanthida'? selsiensis } \\
\text { (Stinton, 1980) [Nolf, 2013] }\end{array}$ \\
\hline \multicolumn{4}{|l|}{ Holocentriformes } \\
\hline Holocentrid indet. & & $\begin{array}{l}\text { Holocentronotus Schwarzhans, } \\
2010 \text { (several species) }\end{array}$ & \\
\hline \multicolumn{4}{|l|}{ Percomorpha indet. } \\
\hline 'Brachygnathus' sp. & $\begin{array}{l}\text { ?Caesio bognoriensis } \\
\text { Stinton, } 1957\end{array}$ & $\begin{array}{l}\text { Brachygnathus' bognoriensis } \\
\text { (Stinton, 1957) }\end{array}$ & Species rejected by Nolf (2013) \\
\hline \multicolumn{4}{|l|}{ Kurtiformes } \\
\hline $\begin{array}{l}\text { Apogon macrolepis } \\
\text { Storms, } 1896\end{array}$ & $\begin{array}{l}\text { Otoliths in situ recorded by } \\
\text { Taverne \& Nolf (1979) }\end{array}$ & & $\begin{array}{l}\text { Apogon macrolepis Storms, } 1896 \\
\text { [Taverne \& Nolf, 1979] }\end{array}$ \\
\hline \multicolumn{4}{|l|}{ Spariformes } \\
\hline $\begin{array}{l}\text { Dentex laekeniensis } \\
\text { Van Beneden, } 1872\end{array}$ & $\begin{array}{l}\text { Otoliths in situ recorded by } \\
\text { Taverne \& Nolf (1979) }\end{array}$ & & $\begin{array}{c}\text { Dentex laekeniensis Van Beneden, } \\
1872 \text { [Taverne \& Nolf, 1979] }\end{array}$ \\
\hline \multicolumn{3}{|l|}{$\begin{array}{l}\text { Apsopelix anglicus } \\
\text { (Dixon, 1850) }\end{array}$} & \\
\hline \multicolumn{4}{|l|}{ Albuliformes } \\
\hline \multirow[t]{2}{*}{ Osmeroides sp. } & Archaealbula Frizzell, 1965 & Osmeroides alabamae (Frizzell, 1965) & $\begin{array}{l}\text { Archaealbula alabamae } \\
\text { Frizzell, } 1965\end{array}$ \\
\hline & Prealbula Frizzell, 1965 & $\begin{array}{l}\text { Osmeroides weileri (Frizzell, 1965) } \\
\text { Osmeroides griffini } \\
\text { (Nolf \& Dockery, 1990) }\end{array}$ & $\begin{array}{l}\text { Preabula weileri Frizzell, } 1965 \\
\text { 'Pterothrissida' griffini Nolf \& } \\
\text { Dockery, } 1990\end{array}$ \\
\hline \multicolumn{4}{|l|}{ Aulopiformes } \\
\hline $\begin{array}{l}\text { Apateodus corneti } \\
\text { (Forir, 1887) }\end{array}$ & & Apateodus sp. & $\begin{array}{l}\text { 'Gempylida' sp. Nolf \& } \\
\text { Stringer, } 1996\end{array}$ \\
\hline \multicolumn{4}{|l|}{ ?Eurypterygii } \\
\hline \multicolumn{4}{|l|}{ Beryciformes } \\
\hline $\begin{array}{l}\text { Hoplopteryx lewesiensis } \\
\text { (Mantell, 1822) }\end{array}$ & & $\begin{array}{l}\text { Hoplopteryx coffeesandensis } \\
\text { (Nolf \& Dockery, 1990) } \\
\text { Hoplopteryx causae (Nolf, 2003) } \\
\text { Hoplopteryx oscitans } \\
\text { (Nolf \& Stringer, 1996) } \\
\text { Hoplopteryx supracretacea } \\
\text { (Koken, 1891) }\end{array}$ & $\begin{array}{l}\text { 'Trachichthyida' coffeesandensis } \\
\text { Nolf \& Dockery, } 1990 \\
\text { 'Trachichthyida' causae Nolf, } 2003 \\
\text { 'Trachichthyida' oscitans Nolf \& } \\
\text { Stringer, } 1996 \\
\text { Antigonia supracretacea } \\
\text { (Koken, 1891) } \\
\text { [Schwarzhans, 2010] }\end{array}$ \\
\hline
\end{tabular}

skeletal remains of which are early Palaeogene in age (Prokofiev 2002; Monsch \& Bannikov 2011). We would therefore advise caution in relating Late Cretaceous otoliths to extant clades, particularly when these associations strongly conflict with first appearances of groups based on skeletal records.

Surprisingly, one of the limitations to the study of in situ otoliths comes not from the perspective of 
FIG. 4. Cladogram showing systematic position of Mesozoic otoliths in situ so far retrieved. Vertical axis without time scale; position of stars reflects relative time scale. Cladogram composed after Nelson et al. (2016).

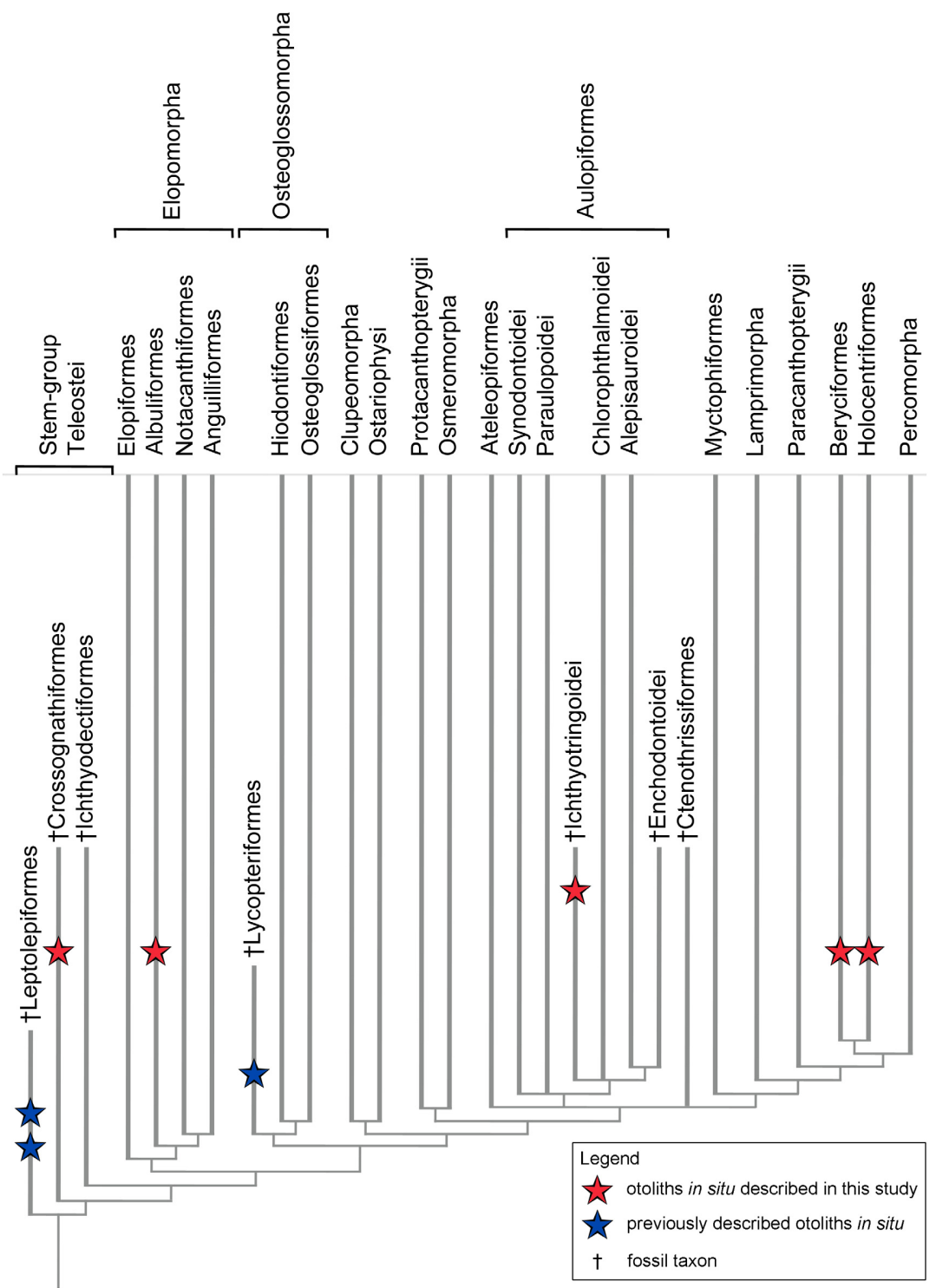

ambiguity surrounding the otoliths themselves, but rather from inadequate documentation of the anatomy and relationships of the skeletal remains that yield them. While some of the skulls examined by us belong to welldescribed, well-circumscribed taxa of clear affinities (e.g. Patterson 1964; Forey 1973), others like Sciaenuropsis, 'Brachygnathus', and the undetermined Gault teleost, have poorly constrained phylogenetic positions due to a combination of limited historical study or deficient skeletal remains, coupled with a past emphasis on complete but flattened fish body fossils preserving articulated postcrania.

The systematic application of $\mu \mathrm{CT}$ to fossil teleosts is in its infancy. It is obviously a promising, non-invasive technology for linking of skeleton- and otolith-based data and it is our hope that this approach will yield significant new data on both skeletal and otolith anatomy that can advance our understanding of these two important kinds of fossil data with a bearing on the evolutionary history of fishes.

\section{SYSTEMATIC PALAEONTOLOGY}

Teleost systematics follow Nelson et al. (2016).

Order CROSSOGNATHIFORMES Taverne, 1989

Family CROSSOGNATHIDAE Woodward, 1901

Genus APSOPELIX Cope, 1871

Diagnosis (otolith). Thin, flat, elongate otolith with deep ventral rim and shallow, flat, horizontal dorsal rim above 
rear part of otolith only. Rostrum massive, about 50\% of otolith length, its dorsal margin flat, horizontal. Ostium wide, long, voluminous; cauda short, straight, narrow.

Remarks. The relationships of Apsopelix and other crossognathiforms is currently debated, with formal phylogenetic analyses placing the group either as crownward members of the teleost stem lineage (Patterson \& Rosen 1977; Arratia \& Tischlinger 2010) or early diverging members of the teleost crown group (Sferco et al. 2015). The otolith morphology of Apsopelix is indeed very plesiomorphic and resembles, as far as discernible, that of even earlier diverging lineages like Leptolepis (i.e. Leptolepis normandica Nybelin, 1962), the earliest teleosts from which in situ otoliths are known (Nolf 2013). Otoliths of stem teleosts are rather similar in appearance, with limited morphological disparity. In the case of Apsopelix, the thin, flat otolith seems to be characteristic with its large ostium, short dorsal rim and the horizontal dorsal margin of the rostrum.

\section{Apsopelix anglicus (Dixon, 1850)}

Figures 3J, 5

Material. NHMUK PV P9890, Gault Clay Formation, Folkestone, UK. Both otoliths preserved in situ, partially as void and partially as replacement with a dense mineral, probably pyrite.

Description. A rather small, delicate otolith of about $6.5 \mathrm{~mm}$ length with poorly resolved surface structures due to a strongly rugose surface and edged margins. The following description is therefore reduced to relatively few discernible features. OL: $\mathrm{OH}=2.0 ; \mathrm{OH}: \mathrm{OT}$ probably $>4$. Otolith shape elongate, with long, projecting, pointed rostrum and angular posterior tip. Dorsal rim very short, only about half of the length of the otolith, shallow, nearly straight, joined to posterior rim in nearly rectangular postdorsal angle. Dorsal rim with feeble indications of excisura and antirostrum. Dorsal rim of rostrum straight. Ventral rim deeply curved with rounded mid-ventral angle.

Inner face rather flat with a poorly resolved sulcus in a slightly supramedian position. Ostium large, wide, particularly ventrally widened, occupying most of rostrum and short stretch behind. Cauda barely discernible, short, straight, narrow. No dorsal depression or ventral furrow apparent.

Remarks. The rather poorly resolved otolith model limits correlation with otolith-based taxa from the Cretaceous. There are, however, some isolated examples that show some resemblance in outline and proportions of otolith and sulcus, particularly in respect to the short dorsal rim and the voluminous ostium. The best example is 'Argentinida' bergantinus Nolf, 2004 from the Aptian of northeastern Spain, which differs in the more compressed shape $(\mathrm{OL}: \mathrm{OH}=1.5-1.6$ vs 2.0$)$ and the inclined instead of horizontal dorsal margin of the rostrum. If indeed a crossognathiform, it would represent a different genus and possibly family. A small number of otolith-based species have been described from the Gault of Folkestone by Stinton (1973) and Nolf (2010). Amongst them is one, Argentina? lobata Stinton, 1973, which resembles Apsopelix anglicus in outline and the thin and fragile appearance, but does not show such a wide ostium or long rostrum. Even when considering the incomplete preservation of all isolated otoliths of Argentina? lobata so far obtained and the relatively poor model retrieved from the in situ otolith of Apsopelix anglicus, it seems unlikely that the two species are synonymous.

Order ALBULIFORMES Jordan, 1923

Family OSMEROIDIDAE Forey, 1973

Genus OSMEROIDES Agassiz, 1837

[= Prealbula Frizzell, 1965; = Archaelbula Frizzell, 1965]

Diagnosis (otolith). Oval otolith with strongly convex inner face and flat outer face. Ostium wide, about $35 \%$ of
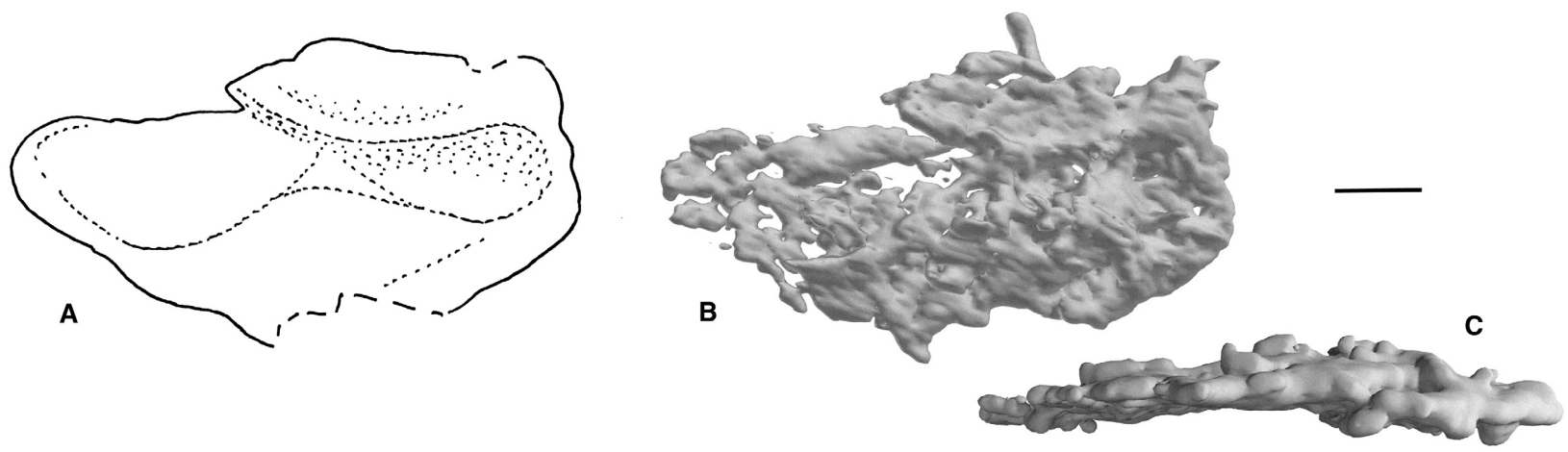

FIG. 5. Scanned in situ otolith of Apsopelix anglicus (Dixon, 1850), Cenomanian-Turonian, English Chalk, NHMUK PV P9890, mirror imaged. A, schematized reconstruction of inner face from CT-scan. B, inner face. C, ventral view. Scale bar represents $1 \mathrm{~mm}$. 
total sulcus length; cauda inclined at about $25^{\circ}$, straight to slightly curved.

Remarks. In a combined analysis of morphological, molecular, and palaeontological data, Dornburg et al. (2015) placed Osmeroides outside the clade containing both Albulidae and Pterothrissidae. The otolith morphology of Osmeroides supports this assessment, since it does indeed exhibit a combination of characters of the Albulidae (strongly convex inner face, open ostium) and Pterothrissidae (inclined position of cauda and cauda not bent ventrally).

The otolith-based genera Prealbula and Archaealbula are synonymized with Osmeroides based primarily on the inclined but unbent cauda, which differs from otoliths of the extant genus Albula. Frizzell (1965) noted the angle of the cauda, the expansion of the posterior rim, and the curvature of the inner face as diagnostic differences between Prealbula and Archaealbula. With many more specimens now available, we regard such variation as significant for specific rather than generic differentiation.

Osmeroides sp.

Figures $3 \mathrm{H}, 6 \mathrm{~A}-\mathrm{D}$

Material. NHMUK PV 39433. Locality information as given on the specimen label is limited to 'Chalk, England' Both otoliths preserved in situ as voids with a dense mineral precipitated around the margins.

Description. A large otolith of about $12.8 \mathrm{~mm}$ length with a low surface rugosity. $\mathrm{OL}: \mathrm{OH}=1.7 ; \mathrm{OH}=\mathrm{OT}=2.3$. Otolith shape elongate, oval. Anterior rim broadly rounded; posterior rim with inferior angle. Dorsal rim moderately high, anteriorly depressed,
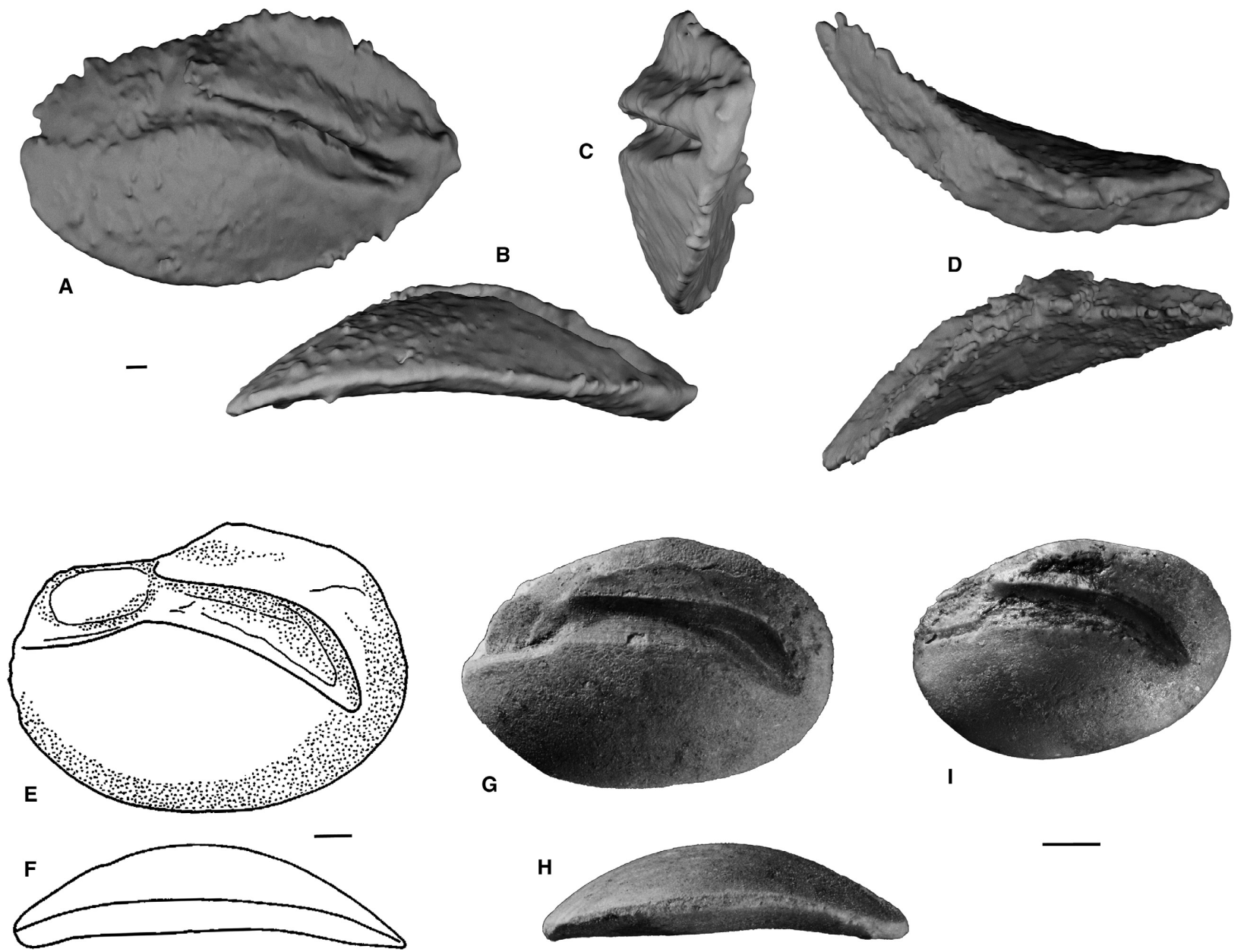

FIG. 6. A-D, scanned in situ otolith of Osmeroides sp., Cenomanian-Turonian, English Chalk, NHMUK PV P39433; A, inner face; $\mathrm{B}$, ventral view; C, posterior view; D, left and right otolith in vivo position from above (mirror imaged). E-F, Osmeroides griffini (Nolf \& Dockery, 1990), Maastrichtian, Mississippi, USA, holotype, IRSNB P 5683 (refigured from Nolf (2013) with the permission of the author); E, inner face; F, ventral view. G-I, Osmeroides weileri (Frizzell, 1965), Santonian, Alabama, USA, LACM 58469-3; G-I, inner faces; $\mathrm{H}$, ventral view. All scale bars represent $1 \mathrm{~mm}$. 
posterodorsally with broad expanded lobe followed by steeply inclined section. Ventral rim very regularly curved, smooth.

Inner face distinctly convex. Sulcus in supramedian position with ostium opening on anterior-dorsal rim. CaL:OsL $=1.6$. Ostium moderately wide, dorsally more widened than ventrally, shallow. Cauda narrow, deeper than ostium, almost straight, inclined at about $25^{\circ}$ against ostium, terminating rather close to posterior rim of otolith. Dorsal depression broad, separated from cauda by distinctly elevated crista superior. Ventral field smooth without ventral furrow. Outer face slightly concave, smooth.

Remarks. This otolith morphology has always been recognized as representing an albulid or pterothrissid. There are a number of otolith-based species, which share the diagnostic characters with the in situ example described for Osmeroides. The closest match with our specimen is O. weileri (Frizzell, 1965) (Fig. 6G-I) from the Santonian of the Gulf Coast, which differs merely in the shallower postdorsal region and the somewhat less inclined and slightly bent cauda. Osmeroides griffini (Nolf \& Dockery, 1990) (Fig. 6E, F) from the Campanian of Mississippi is more compressed than both Osmeroides sp. and O. weileri from the late Santonian of Alabama, and O. alabamae (Frizzell, 1965) from the Paleocene of Alabama finally is the most elongate form. Osmeroides apparently is common in otolith associations of the Late Cretaceous.

\section{Order AULOPIFORMES Rosen, 1973 Suborder ICHTHYOTRINGOIDEI Jordan, 1905 Family ICHTHYOTRINGIDAE Jordan, 1905}

\section{Genus APATEODUS Woodward, 1901}

Diagnosis (otolith). Thin, slender otolith with a long, pointed rostrum about the length of the remainder of the otolith. Ostium wide, though ventrally only moderately widened, shallow; cauda deep, narrow, slightly flexed towards rear, terminating very close to posterior rim of otolith.

\section{Apateodus corneti (Forir, 1887)}

Figures 3G, 7A-C

Material. RGM 446950, Maastricht Formation, Valkenburg aan de Guel, the Netherlands. Both otoliths preserved as voids, slightly displaced from life position.

Description. A large, thin and delicate otolith of about $13.8 \mathrm{~mm}$ length with a low surface rugosity. $\mathrm{OL}: \mathrm{OH}=1.85 ; \mathrm{OH}$ : $\mathrm{OT}=6.0$. Otolith shape elongate, with rounded posterior portion and sharply pointed and exceptionally long rostrum. Dorsal rim high, deeply lobate, but without any prominent angles, its extend limited to area behind ostial opening. Dorsal rim of ostium straight, ascending, symmetrical to ventral rim along rostrum. Ventral rim almost straight anteriorly and ascending to rostral tip, more regularly and deeply curved posteriorly. Posterior rim with obtuse inferior angle below tip of cauda.

Inner face slightly convex. Sulcus positioned along axis of otolith, with ostium opening on anterior-dorsal rim. CaL: $\mathrm{OsL}=1.3$. Ostium wide, ventrally less widened than dorsally, shallow. Its dorsal margin curving upwards right at ostial-caudal joint to meet dorsal rim. Cauda moderately wide and deep, rather straight, but slightly inclined towards tip and slightly widened dorsally before tip. Caudal tip reaching very close to posterior rim of otolith. Dorsal depression not clearly developed. Ventral field smooth without ventral furrow. Outer face slightly concave, smooth. Otolith very thin in lateral view, particularly its rostrum.

Remarks. Nolf \& Stringer (1996) reported a number of fragmented otoliths from Santonian, Campanian and Maastrichtian rocks of Mississippi and Alabama that they interpreted as belonging to gempylids, a group of percomorph fishes. This substantially predates the body fossil record of this group, which begins near the Paleocene-Eocene boundary (Prokofiev 2002). In fact, these Cretaceous otoliths show a striking correspondence with the in situ otolith of Apateodus corneti including: shape and depth of cauda, proportions of the rear part of the otolith, the caudal tip extending to the posterior rim, and the overall thinness of the otoliths themselves. The rostrum is not preserved in any of the isolated specimens so far obtained, which is easy to understand given how delicate this structure appears in our in situ examples for A. corneti. We interpret these Cretaceous

FIG. 7. A-C, scanned in situ otolith of Apateodus corneti (Forir, 1887), Maastrichtian, Maastricht, Netherlands, RGM 446950 (left otolith, mirror imaged); A, inner face; B, posterior view; C, ventral view. D-G, Apateodus sp., Santonian, Alabama, USA, LACM 58469-20; D-E, inner face; F, posterior view; G, ventral view. H, Scopelosaurus lepidus (Krefft \& Maul, 1955), Recent, coll. Schwarzhans. I, Chlorophthalmus acutifrons Hiyama, 1940, Recent, Indonesia, BMNH 1986.8.21.1. J, Bathysaurus ferox Günther 1878, Recent, $44^{\circ} \mathrm{N}, 03^{\circ} \mathrm{W}$, coll. Schwarzhans (leg. FBH). K, Bathypterois bigelowi Mead, 1958, Recent, $17^{\circ} 37^{\prime} \mathrm{N}, 62^{\circ} 48^{\prime} \mathrm{W}$, coll. Schwarzhans (leg. FBH). L, Gigantura vorax Regan, 1925, Recent, $07^{\circ} \mathrm{N}, 20^{\circ} \mathrm{W}$, coll. Schwarzhans (leg. FBH). M, Ipnops murrayi Günther 1878 , Recent, $28^{\circ} 33^{\prime} \mathrm{N}, 88^{\circ} 21^{\prime} \mathrm{W}$, ZMUC P23449-50. N, Scopelarchus candelops Rofen, 1963, Recent, $11^{\circ} \mathrm{N}, 26^{\circ} \mathrm{W}$, coll. Schwarzhans (leg. FBH). O, Sudis hyalina Rafinesque, 1810 , Recent, $27^{\circ} \mathrm{N}, 52^{\circ} \mathrm{W}$, coll. Schwarzhans (leg. FBH). P, Lestidiops similis (Ege, 1933 ), $33^{\circ} \mathrm{N}$, $39^{\circ} \mathrm{W}$, coll. Schwarzhans (leg. FBH). Q, Magnisudis atlanticus (Krøyer, 1868), Recent, coll. Schwarzhans (leg. Fitch). R, Coccorella atlantica (Parr, 1928), Recent, $30^{\circ} \mathrm{N}, 66^{\circ} \mathrm{W}$, coll. Schwarzhans (leg. FBH). S, Omosudis lowii Günther, 1887, Recent, Anton Dohrn st. 301-79, coll. Schwarzhans (leg. ZMUC). T, Alepisaurius ferox Lowe, 1833, Recent, New Caledonia, from Lombarte et al. (2006). H-T, inner faces. All scale bars represent $1 \mathrm{~mm}$. 

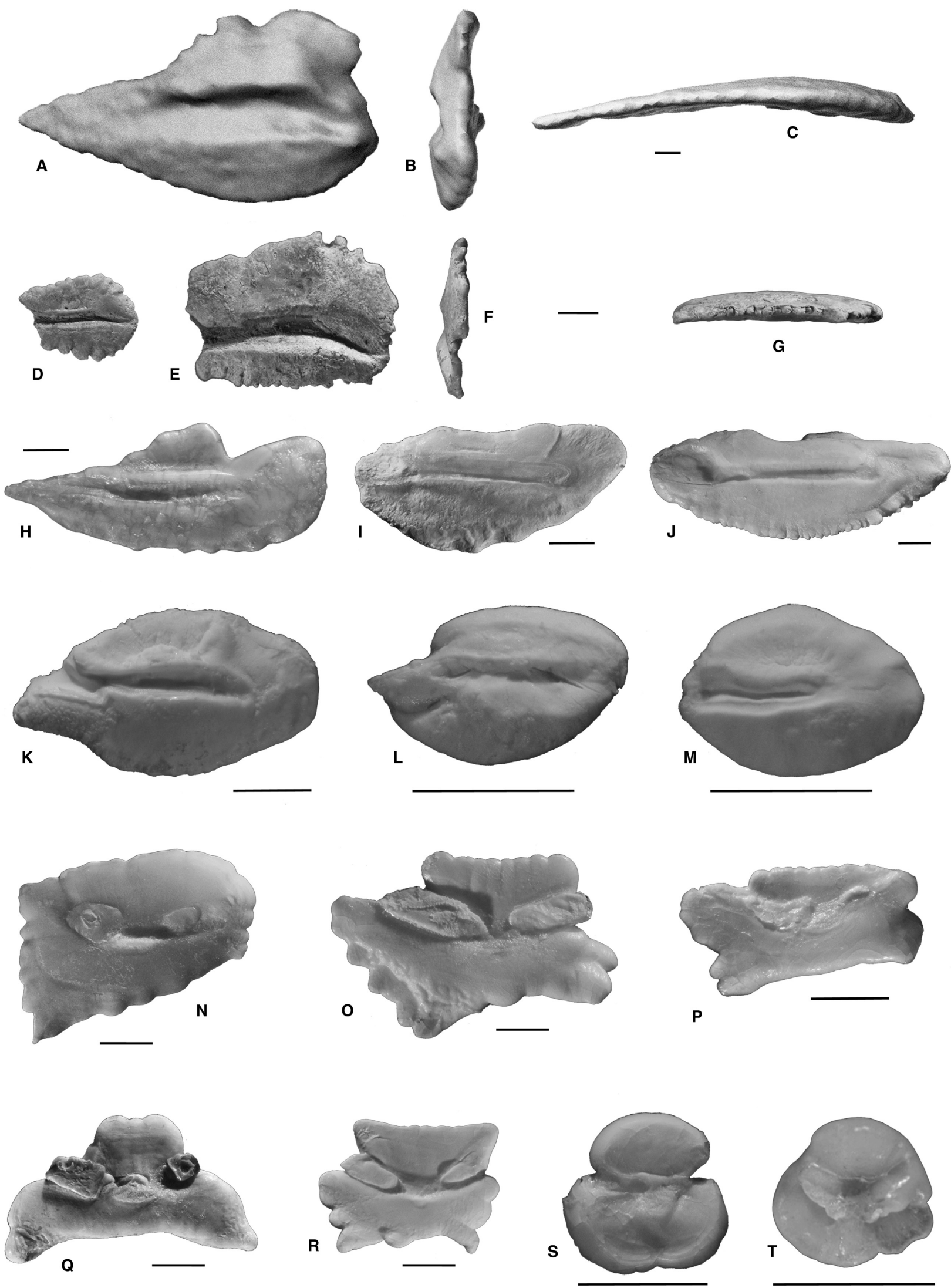
otoliths of putative gempylids instead representing Apateodus or a closely related aulopiform. The isolated otoliths differ from those of A. corneti in the longer dorsal section, the shallower ventral rim (at least in large specimens), and the presence of an antirostrum and excisura immediately before the area where the rostrum has broken off in most instances (Fig. 7D-G). Apateo$d u s$ first appeared in the late Early Cretaceous (Albian) and extended to the end of the Late Cretaceous, being known from several localities throughout that interval (Newbrey \& Konishi 2015). Our reinterpretation of these Late Cretaceous otoliths as belonging to that genus is thus more consistent with the body fossil record than past identifications. Otoliths of fast swimming, epipelagic predators often converge on a common morphology: slender, thin, richly sculptured and with a deep cauda and a long, pointed rostrum. Superficially similar otoliths are hence found in a number of other epipelagic fishes such as Elopidae (otoliths thicker and differing shape of ostium and rostrum) or Carangidae (strongly curved cauda and bent inner and outer faces). For instance Nolf (1995) documented that Lates stappersii (Boulenger, 1914), an endemic epipelagic predator in Lake Tanganyika thought to have derived from the Nile perch (Lates niloticus), evolved an otolith morphology very similar to unrelated carangids and scombrids, suggestive of anatomical convergence as a consequence of shared ecology.

The phylogenetic position of Apateodus within Aulopiformes is unclear, being considered a representative of the Ichthyotringoidei, an extinct aulopiform suborder (Davis \& Fielitz, 2010). However, it has also been routinely aligned with the Alepisauroidei (Rosen 1973; Newbrey \& Konishi 2015; Beckett et al. 2017). We have studied otoliths of all extant aulopiform families and figure specimens representing all families of Alepisauroidei for comparison: Notosudidae: Scopelosaurus lepidus (Krefft \& Maul, 1955) (Fig. 7H); Chlorophthalmidae: Chlorophthalmus acutifrons Hiyama, 1940 (Fig. 7I); Bathysauropsidae: Bathysaurus ferox Günther, 1878 (Fig. 7J); Bathypteroidae: Bathypterois bigelowi Mead, 1958 (Fig. 7K); Giganturidae: Gigantura vorax Regan, 1925 (Fig. 7L); Ipnopidae: Ipnops murrayi Günther, 1878 (Fig. 7M); Scopelarchidae: Scopelarchus candelops Rofen, 1963 (Fig. 7N); Sudidae: Sudis hyalina Rafinesque, 1810 (Fig. 7O); Paralepididae: Lestidiops similis (Ege, 1933) (Fig. 7P) and Magnisudis atlanticus (Krøyer, 1868) (Fig. 7Q); Evermannellidae: Coccorella atlantica (Parr, 1928) (Fig. 9R); Alepisauridae: Omosudis lowii Günther, 1887 (Fig. 7S) and Alepisaurius ferox Lowe, 1833 (Fig. 7T). Our observations highlight two contrasting otolith morphologies within species of Alepisauroidei, with implications for the phylogenetic placement of Apateodus. The first of these is distinguished by a narrow, deepened cauda and a short, variably wide ostium, both without elevated colliculi. This arrangement characterizes all constituent families of the suprafamilies Ipnopoidea, Chlorophthalmoidea and Notosudoidea. There are individual variations that are probably autapomorphic traits of particular families: notosudid otoliths are remarkable for their long and pointed rostrum and the ostium being narrower than the cauda, giganturid otoliths exhibit a distinct groove below the ostium, and ipnopid otoliths show no clear division of ostium and cauda. However, the general morphologies of these otoliths correspond broadly to those of the more deeply branching aulopoids and paraulopoids, indicating that this overall geometry is primitive for Aulopiformes.

By contrast, the pattern found in species of Alepisauroidea is highly specialized and characterized by several clear-cut synapomorphies. The sulcus bears distinctly elevated and prominent ostial and caudal colliculi (except in Alepisauridae, where they are flat), which are widely separated from each other. The collum in between the colliculi occasionally shows a ventral pseudocolliculum (Scopelarchidae, Paralepididae) and the colliculi sometimes project beyond the otolith margins anteriorly and posteriorly (Sudidae, Paralepididae, Evermannellidae). A similarly bizarre sulcus morphology otherwise is only found in certain gadiforms and zeiforms (see Nolf 2013), but in Alepisauroidea a strongly projecting and pointed preventral angle and much reduced dorsal and ventral otolith margins further contribute to a distinctive otolith morphology (except in Alepisauridae). Parsimony suggests that the unusually small and round otoliths of Alepisauridae represent a secondary reduction.

Otoliths of Apateodus show distinctive characters including a long and sharp rostrum, a relatively wide cauda, and an abbreviated but high dorsal rim, but these appear to be general features of aulopiforms. The genus lacks any of the derived otolith features of Alepisauroidea, the group to which most fang-bearing Cretaceous aulopiforms have been attributed (Rosen 1973), and thus does support a placement with that superfamily. Recent analysis of gill-arch anatomy in Apateodus, however, provides some support for a relationship with paralepidids, but the genus also shows features conflicting with this interpretation (Beckett et al. 2017). Otolith characters, which strongly contradict placement of the genus within Alepisauroidea, should be included in future analyses attempting to place Apateodus within aulopiform phylogeny.

\section{Order GADIFORMES Goodrich, 1909 Suborder GADOIDEI Goodrich, 1909 INCERTAE FAMILIAE}

\author{
Genus RHINOCEPHALUS Casier, 1966 \\ Rhinocephalus planiceps Casier, 1966 \\ Figures 3C, 8A-F
}
1966 Rhinocephalus planiceps Casier, pl. 55 figs 1-3, pl. 56 figs $1-3$.
1977 Merluccius nodosus Stinton, pl. 6 figs 14-15. [oto- lith-based species]

Material and locality. NHMUK PV P65195, London Clay Formation, Isle of Sheppey, UK. Both otoliths preserved in situ, and completely replaced with a dense material, probably pyrite.

Description. Each otolith is large, approximately $12.5 \mathrm{~mm}$ in length, with moderately rugose surface. $\mathrm{OL}: \mathrm{OH}=2.5 ; \mathrm{OH}$ : $\mathrm{OT}=2.7$. Otolith elongated, with a pointed, projecting, posterior tip and a rounded anterior tip, both along median axis of 


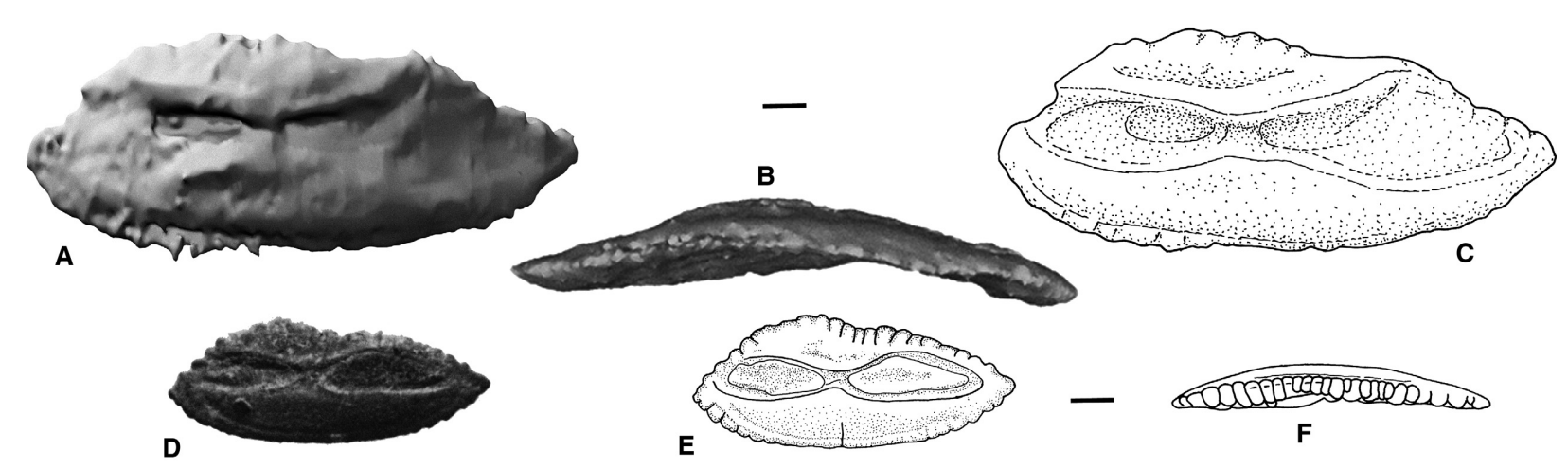

FIG. 8. A-C, scanned in situ otolith of Rhinocephalus planiceps Casier, 1966, Eocene (Ypresian), London Clay Formation, NHMUK PV P65195; A-C, left otolith, mirror imaged; A, inner face; B, ventral view; C, interpretative drawing of scanned inner face, incorporating details of the sulcus visible on the right otolith. D-F, otolith-based species Merluccius nodosus Stinton, 1977 [syn. Rhinocephalus planiceps], Eocene, Lutetian, southern England, holotype, NHMUK PV P56371, mirror imaged; D, inner face (refigured from Stinton 1977; CThe Palaeontographical Society, reproduced with permission); E, inner face; F, ventral view (E-F, refigured from Nolf (2013) with the permission of the author). Scale bars represent $1 \mathrm{~mm}$.

otolith. Dorsal rim with broad, rounded, rather low predorsal lobe and low postdorsal angle positioned at about 30\% from posterior tip. Short stretch of dorsal rim between predorsal lobe and postdorsal angle mildly concave. Ventral rim shallow, anteriorly and posteriorly regularly curved, nearly straight at its central portion.

Inner face distinctly convex with slightly supramedian sulcus reaching close to anterior-dorsal and posterior-dorsal rims of otolith. Ostium somewhat shorter than cauda, with shallow dorsal and deep ventral margin. Ostial-caudal joint (collum) narrow, incised from ventral, probably without pseudocolliculum. Cauda slightly larger than ostium with dorsally and ventrally widened rims. Colliculi well marked in right otolith specimen, large, oval in shape and somewhat deepened. Dorsal depression narrow, only above central part of sulcus. Ventral furrow distinct and close to ventral rim of otolith. Outer face distinctly concave.

Remarks. The overall shape of the left otolith is well preserved, but the sulcus morphology is less clear (Fig. 8A$\mathrm{C}$, shown reversed). However, the right otolith reveals more detail of the sulcus which has been incorporated into the interpretative drawing (Fig. 8C).

Discussion and correlation with isolated otoliths. Casier (1966) described Rhinocephalus as close to the extant Merluccius, a view reiterated by Fedotov (1976) and Fedotov \& Bannikov (1989). We were unable to identify morphological features of the otoliths that would distinguish them from those of Merluccius. However, Endo (2002, p. 134) noted clear osteological differences between the supsensoria of Merluccius and Rhinocephalus, and regarded the latter as the probable sister lineage of a clade comprising Merlucciidae plus seven other gadiform families.

Stinton (1977) described Merluccius nodosus from otoliths up to $6.7 \mathrm{~mm}$ in length, from the middle Eocene (Lutetian) Brackelsham Group of the UK (Fig. 8D-F). These resemble the in situ otoliths of $R$. planiceps in all aspects so well that we have little doubt in synonymizing the two species, despite the stratigraphic difference and the fact that comparable otoliths so far have not been obtained from the London Clay Formation. Palaeogadus serratus Stinton, 1966 from the London Clay Formation appears to be a typical representative of the genus Palaeogadus, a taxon for which in situ otoliths have been described by Novitskaya (1961) and Fedotov (1976). Otoliths of Palaeogadus resemble those of Merluccius and Rhinocephalus to a large extent, but differ in having an ostium that is much narrower and shorter than the cauda, the absence of a postdorsal angle, and an anterior tip more strongly pointed than the posterior tip. Another species of Palaeogadus (P. shepherdi Schubert, 1916) is known from the Bartonian. Other similar, but more compressed otoliths include Merluccius? papillosus (Stinton, 1966) from the Lutetian, M.? antiquus Schwarzhans \& Bratishko, 2011 from the Selandian of Ukraine and Euclichthys lawsoni Nolf \& Rundle in Nolf, 2013 from the Ypresian of southern England. They most likely represent another genus of merlucciid-like gadiform. Extending from the middle Paleocene (Selandian) to middle Eocene (Lutetian), these are among the oldest gadiforms outside the informally described Danian 'Protocodus' from West Greenland (Cohen 1984).

Order HOLOCENTRIFORMES Patterson, 1993b
Family HOLOCENTRIDAE Bonaparte, 1833

Genus INDET.

Figures 3F, 9A-C

Material. NJSM GP12145, Hornerstown Formation, Inversand Quarry, Sewell, New Jersey, USA. Both otoliths preserved as a void partially infilled with a dense mineral. 

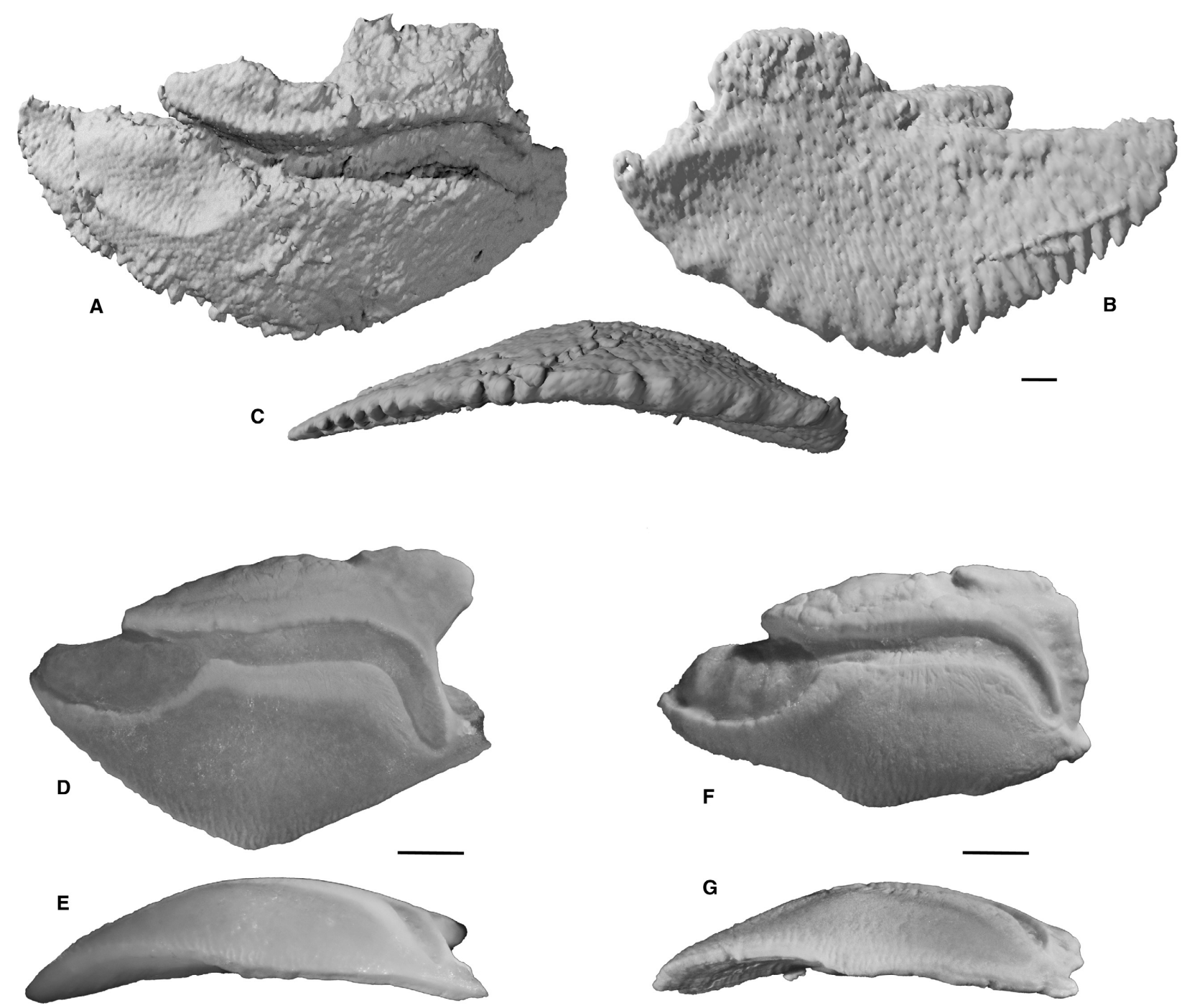

FIG. 9. A-C, scanned in situ otolith of an unspecified holocentrid, Maastrichtian-Danian, Hornerstown Formation, NJSM GP12145; A, inner face; B, outer face; C, ventral view. D-E, Sargocentron violaceum (Bleeker, 1853), Recent, Samoa, coll. Schwarzhans (leg. ZMH); D, inner face; E, ventral view. F-G, Neoniphon argenteus (Valenciennes), Recent, Samoa, coll. Schwarzhans (leg. ZMH); F, inner face; $\mathrm{G}$, ventral view. All scale bars represent $1 \mathrm{~mm}$.

We also examined NJSM GP12381, which preserves otoliths in a less satisfactory state. These fossils are mentioned, but not described, by Stewart (1996).

Description. A large otolith, $17.4 \mathrm{~mm}$ in length. $\mathrm{OL}: \mathrm{OH}=1.65-$ 1.8; $\mathrm{OH}: \mathrm{OT}=3.5$. Otolith shape elongate, with very long and pointed, but not very thin rostrum. Dorsal rim mostly low, anteriorly depressed behind distinct antirostrum, than expanded above middle section of cauda and finally deeply depressed again and concave leading to the angular posterior tip. Dorsal rim of rostrum straight, nearly horizontal and reaching into a sharp and moderately deep excisura. Ventral rim moderately deep, regularly curved, deepest at its middle. Anterior half of ventral rim intensely and regularly serrated.

Inner face distinctly convex. Sulcus distinctly supramedian, with ostium opening on anterior-dorsal rim. CaL:OsL $=1.3$.
Ostium wide, ventrally strongly widened, dorsally flat, slightly bent upwards to tip of antirostrum, rather deep. Cauda long, deep, anteriorly slightly upwards directed, posteriorly with a distinct downward bent at an angle of about $25-30^{\circ}$, terminating very close to posterior tip of otolith. Dorsal depression narrow, distinct, ventrally well marked by crista superior above cauda and dorsally by a kink-step against inclined uppermost portion of expanded median part of dorsal field. Ventral field smooth, seemingly without ventral furrow. Outer face distinctly concave, with short furrows originating vertically from serration of anterior ventral rim, otherwise smooth. Otolith moderately thin in lateral view; anterior and posterior views show distinct incision of cauda.

Remarks. This otolith derives from an undescribed holocentrid skull, previously interpreted as intermediate between Cretaceous stem holocentrids and members of 
the two modern subfamilies, the earliest definitive members of which are Maastrichtian and early Eocene for otolith and skeletal data, respectively (Stewart 1984, 1996; Schwarzhans 2010). The otolith differs from those of extant holocentrid genera only in the lesser angle of the caudal bend $\left(70^{\circ}\right.$ to nearly $90^{\circ}$ in Sargocentron and 45$75^{\circ}$ in Neoniphon; Rivaton \& Bourret 1999; Schwarzhans 2010). Figured Recent otoliths for comparison are: Sargocentron violaceum (Bleeker, 1853) (Fig. 9D, E) and Neoniphon argenteus (Valenciennes) (Fig. 9F, G). Similar otolith-based fossil species have been referred to the otolith-based genus Holocentronotus: H. percomorphus Schwarzhans, 2010 from the Maastrichtian of Bavaria, H. ryabchuni Schwarzhans \& Bratishko, 2011 from the Paleocene of Ukraine, H. blandus Schwarzhans, 2012 from the Paleocene of Bavaria, and H. amplus (Schwarzhans, 1980), H. palasulcatus (Schwarzhans, 1980) and H. ventricosus (Schwarzhans, 1980) all from the Eocene of New Zealand. None of them reach the size of the scanned otolith from the New Jersey Greensand and none show the reduced dorsal rim. Nevertheless, the pattern is sufficiently similar to assume that it could belong to the same or a closely related genus.

It should be noted that holocentrin otoliths can be easily confused with a number of percomorph otoliths with which they share the advanced heterosulcoid sulcus pattern (large ostium, narrow cauda which is bent ventrally at its rear part; by contrast myripristin otoliths are highly specialized: Schwarzhans 2010). There are a few subtle differences, which may help in distinguishing in most instances, such as the lack of a ventral furrow in holocentroids or the dorsally not widened ostium. However, this might not be reliable in all cases.

\section{Order BERYCIFORMES Regan, 1909 \\ Suborder BERYCOIDEI Regan, 1909 \\ Family BERYCIDAE Lowe, 1839}

\section{Genus SCIAENUROPSIS Casier, 1966}

Diagnosis (otolith). High bodied otolith with deep ventral rim and shallow dorsal rim. Ostium ventrally much widened and about as long as cauda; cauda distinctly upwards bent and very slightly flexed at tip close to posterior rim of otolith.

\section{Sciaenuropsis lerichei (Schubert, 1916) [= Sciaenuropsis turneri Casier, 1966] Figures 3D, 10A-E}

1916 Monocentris? lerichei Schubert, pl. 7 figs 7-8. [otolith-based species]

\author{
1966 Sciaenuropsis turneri Casier, pl. 30. \\ 1978 Beryx lerichei (Schubert, 1916); Stinton, pl. 10 \\ figs $10-11$. \\ 1978 Beryx nova Stinton, 1977; Stinton, pl. 10 fig. 9. \\ [otolith-based species] \\ ?1980 Pristigenys bella Stinton: pl. 13 figs 27-28. [otolith- \\ based species] \\ $2007 b$ genus Epogonidarum lerichei (Schubert, 1916); Sch- \\ warzhans, fig. 29A-E.
}

Material. NHMUK PV P6444a, London Clay Formation, Sheppey, UK. Both otoliths preserved in situ as original bone, partially enclosed in pyrite.

Description. Each otolith is large, with a length of about $14.2 \mathrm{~mm}$. The surface is moderately rugose, which might reflect preservation. $\mathrm{OL}: \mathrm{OH}=1.15 ; \mathrm{OH}: \mathrm{OT}=3.7$. Otolith shape high bodied, compact. Anterior rim with short, supramedian positioned rostrum, small and narrow excisura and broad, indistinct antirostrum. Dorsal rim high, with broad predorsal angle and pronounced, projecting, nearly rectangular postdorsal angle positioned far backwards at junction with nearly vertically cut posterior rim. Dorsal rim apparently broadly crenulated or undulating. Ventral rim very deep, with distinct angle at deepest point below rear end of ostium and slightly in front of vertical axis of otolith, and with distinct angle at junction with posterior rim located below level of rostrum.

Inner face moderately convex with slightly supramedian sulcus. Ostium very wide with much expanded ventral rim but no expanded dorsal rim, nearly as long as cauda, slightly bent upwards towards anterior opening. Cauda narrow, deeper than ostium and slightly longer, distinctly bent upwards. Caudal tip slightly bent, terminating close to posterior rim of otolith. Dorsal depression well marked, wide and deep, extending above entire sulcus. Ventral field smooth without discernable furrow. Outer face flat.

Remarks. The fossil named as Sciaenuropsis turneri has been subjected to two principal taxonomic interpretations. Agassiz (1845) and Woodward (1901) regarded it as similar to the holocentroid Myripristis (as 'Myripristis toliapicus'), a view subsequently rejected by Casier (1966) on proportional grounds. Instead, he was struck by apparent similarities with the sparid Sparnodus and erected the new genus Sciaenuropsis (Casier 1966, p. 218). Friedman et al. (2016) listed Sciaenuropsis as a holocentroid in their faunal list of the London Clay, reviving the 'classical' interpretation of this fossil, although this placement was proposed without any supporting evidence.

The otolith model retrieved from the specimen provides some evidence bearing on phylogenetic affinities. The otolith of Sciaenuropsis is inconsistent with those of both sparids and holocentroids. The wide ostium, upward turned and nearly straight cauda and the pentagonal outline with the deep ventral rim correspond broadly to 


\section{A}

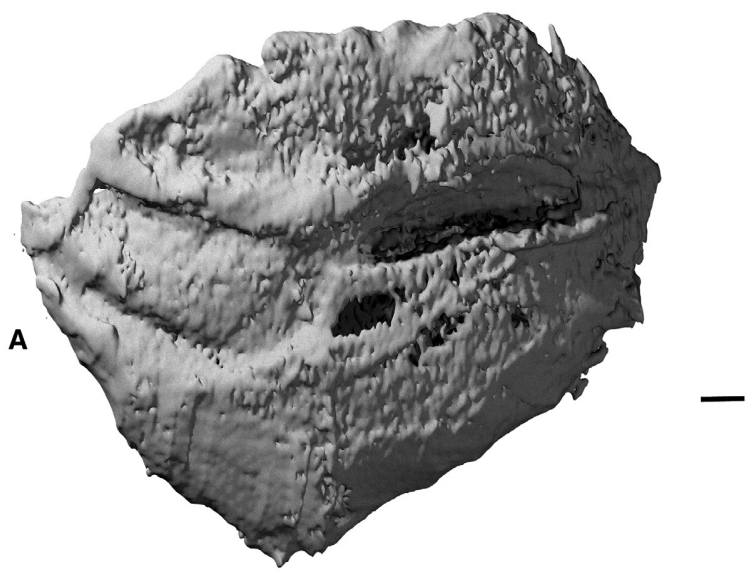

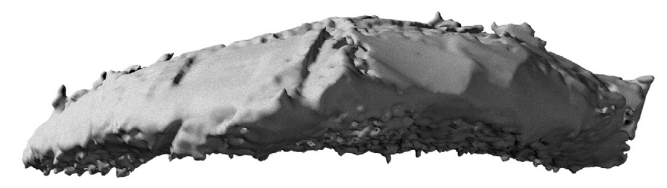

B
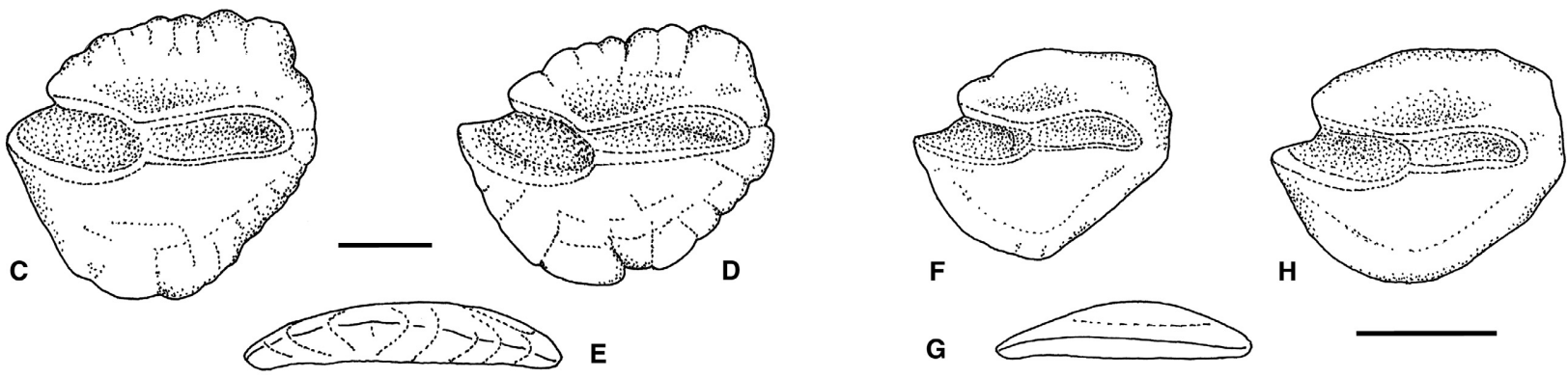

FIG. 10. A-E, Sciaenuropsis lerichei (Schubert, 1916) [syn. Sciaenuropsis turneri Casier, 1966]; A-B, scanned in situ otolith, Eocene, Ypresian, London Clay, NHMUK PV P6444a; A, inner face; B, ventral view; C-E, isolated otolith specimens of S. lerichei, Eocene, Lutetian, northern Germany, SMF P64510; C-D, inner faces; E, ventral view. F-H, otolith-based species Sciaenuropsis selsiensis (Stinton, 1978), Eocene, Lutetian, northern Germany, SMF P64511; F, H, inner faces; G, ventral view. All scale bars represent 1 mm.

otoliths of some berycids and trachichthyoids, but also certain percomorph families, notably the Priacanthidae (see Taverne \& Nolf 2010) and Epigonidae. It is in these two distantly related acanthopterygian groups that isolated otoliths of this kind have also been placed at times (Taverne \& Nolf 2010; Schwarzhans 2007b). It is clear that the features used to identify these taxa are homoplastic or primitive. However, there are two subtle, but seemingly consistent, differences between percomorph and non-percomorph examples. First, berycid and trachichthyoid otoliths show only a ventrally, not dorsally widened ostium, while the ostium is also somewhat expanded dorsally in Priacanthidae. Second, the ostium and cauda are nearly equally long in beryciforms while the ostium is distinctly shorter than the cauda in Priacanthidae and Epigonidae. We do not feel confident making a systematic placement of Sciaenuropsis on the basis of otolith anatomy alone. Although skeletal anatomy of the genus is not well known, there are two relevant features visible externally: well-developed ridges extending the length of the frontals and converging anteriorly as a ' $\mathrm{V}$ '; and sclerotic ossicles. Neither is present in priacanthids (Starnes 1988) or epigonids (Fraser 1972), but both are typical of berycids (Zehren 1979).
There are many similar looking isolated otoliths in the northern European Eocene. Several of them are interpreted as priacanthids such as Pristigenys rutoti (Leriche, 1905), P. rhombicus (Schubert, 1906) or P. hermani Taverne \& Nolf, 2010 (based on articulated skeletons with associated otoliths). However, their placement with Pristigenys has recently been rejected by Carnevale et al. (2017). Others, which lack the dorsally expanded ostium and have an ostium nearly as long as the cauda, are here placed in Sciaenuropsis, all from the North Sea Basin: S. lerichei (Schubert, 1916) (Fig. 10C-E), S. selsiensis (Stinton, 1978) (Fig. 10F-H) and S. bella (Stinton, 1980). None of these otoliths are preserved in association with skeletal remains. However, specimens of S. lerichei to about $5 \mathrm{~mm}$ length match nearly perfectly the morphology of those of S. turneri, including sulcus shape and proportions, and otolith outline including the distinctive expanded backward located postdorsal angle. We have little doubt that these two nominal species, the one based on skeletal remains (S. turneri) the other otolith-based (S. lerichei) represent the same species. In this case S. lerichei (Schubert, 1916) gains priority. It must be noted though that Taverne \& Nolf (2010) figured otoliths 
as genus Priacanthidarum lerichei that are much more elongate with a much narrower sulcus and which probably represent a different, unrelated species. Sciaenuropsis lerichei is known from the middle Eocene (Lutetian and Bartonian). Another species from the Ypresian of the London Clay, S. bella, is tentatively placed in synonymy, differing somewhat in the narrower and shorter ostium. Sciaenuropsis selsiensis from the Lutetian appears to be a small species and differs first of all in the distinctly narrower ostium.

\section{Suborder TRACHICHTHYOIDEI Bleeker, 1856 Family TRACHICHTHYIDAE Bleeker, 1856}

\section{Genus HOPLOPTERYX Agassiz, 1838}

Diagnosis (otolith). Thin, high bodied otolith with flat inner face, an apparently short, massive rostrum, a deep preventral angle and a strongly expanded postdorsal lobe. Ostium moderately wide, dorsally not widened; cauda deep, narrow, distinctly turned upwards towards posterior.

Remarks. Otoliths of Hoplopteryx resemble those of many trachichthyoids and berycoids, characterized by the combination of a high-bodied profile, a ventrally widened ostium and an upwardly bent cauda. There is a particularly close correspondence with the extant trachichthyids Trachichthys Shaw and Hoplostethus Cuvier (see Stinton 1966; Kotlyar 1996; Schwarzhans 2010, 2012; Nolf 2013). Hoplopteryx shares with Trachichthys the compressed shape and the deep ventral rim, but differs in the totally flat inner face and the ostium not being as much ventrally expanded. Otoliths of Hoplostethus are characterized by distinct and nearly equally developed pre- and post-ventral angles, the anterior-dorsal rim being much reduced and the ostium being very wide. Otoliths of other extant trachichthyoid families differ in their specific development of the sulcus with fused colliculi (Anoplogasteridae, Anomalopidae), or the very high, compressed shape of the otolith as a whole (Diretmidae, Monocentridae) (see Nolf 2013).

While a trachichthyoid affinity for Hoplopteryx matches past interpretations (Patterson 1964, 1993a; Gayet 1982; Moore 1993), the close correspondence of otolith shape between this genus and trachichthyids specifically is surprising. Despite their generalized appearance in comparison to other, anatomically divergent trachichthyoid lineages, trachichthyids nest highly within Trachichthyoidei in both molecular and morphological phylogenies (although exact patterns of relationships differ: Moore 1993; Dornburg et al. 2017), rather than as the sistergroup of all remaining members of the clade. Hoplopteryx lacks all three derived characters reported by Moore (1993) as shared by extant trachichthyoids, and is regarded by him and other authors (Gayet 1982; Patterson 1993a) as a stem trachichthyoid. Additionally, Hoplopteryx lacks the single osteological synapomorphy of Trachichthyidae recognized by Moore (1993): a posteriorly pointing spine on the posttemporal. If Hoplopteryx is a trachichthyid, as suggested by otolith morphology, then we must invoke considerable homoplasy in these skeletal features. On the other hand, if Hoplopteryx is a stem trachichthyoid, it implies either the persistence of a primitive otolith morphology in trachichthyids or a reversal to a plesiomorphic geometry in that group.

Hoplopteryx was a widespread taxon in shallow marine deposits during the Late Cretaceous (Patterson 1964; Friedman 2012; Grandstaff \& Parris 2016). The first otolith-based records of Trachichthys date back to the early Paleocene (Schwarzhans 2012) and those of Hoplostethus to the middle Paleocene (Schwarzhans 2003, 2004). It appears that the separation of the two principal extant genera of the Trachichthyidae (Trachichthys and Hoplostethus) occurred near the Cretaceous-Palaeogene boundary. While Trachichthys remained as a secondary endemic to the shelf seas of temperate Australia, Hoplostethus probably expanded into the deep sea at around the Eocene-Oligocene boundary (Schwarzhans 1985) and the establishment of a psychrosphere in the deep oceans, which has since become its principal habitat (Kotlyar 1996).

Hoplopteryx lewesiensis (Mantell, 1822) Figures 3I, 11A-D

Material. NHMUK PV OR41105, Grey Chalk Subgroup, English Chalk Group, Halling, Kent, UK. Both otoliths preserved in situ, completely replaced by a dense mineral.

Description. A moderately large, thin and apparently fragile otolith of about $11.2 \mathrm{~mm}$ length with a moderate surface rugosity and some erosion along the rims. $\mathrm{OL}: \mathrm{OH}=0.85 ; \mathrm{OH}$ :OT about 8.0. Otolith shape high bodied, distinctly higher than long, with incompletely preserved but apparently blunt anterior rim. Dorsal rim high, probably lobate, with prominent postdorsal lobe and somewhat anteriorly depressed. Ventral rim very deep, with prominent preventral angle located below rear margin of ostium; no postventral angle. Posterior rim slightly bent, nearly straight, distinctly inclined at an angle of about $60^{\circ}$ connecting rear angle of postdorsal lobe with deep preventral angle.

Inner face almost perfectly flat. Sulcus distinctly supramedian, with ostium opening on anterior rim. CaL:OsL about 1.0 or slightly less. Ostium moderately wide, ventrally distinctly widened, dorsally not widened but gently bending upwards towards opening, somewhat deepened. Cauda narrow and deep, 

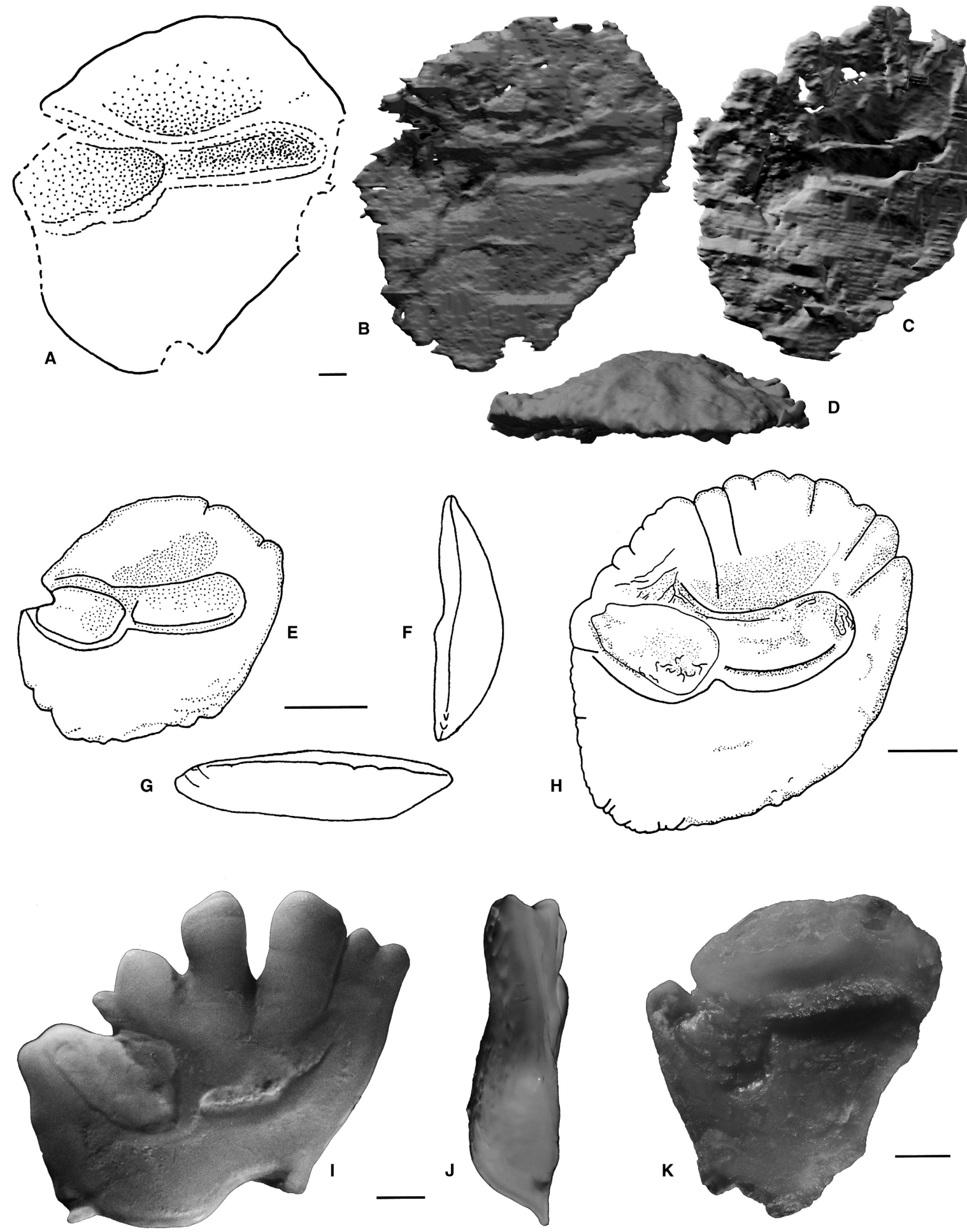

FIG. 11. A-D, scanned in situ otolith of Hoplopteryx lewesiensis (Mantell, 1822), Cenomanian-Turonian, English Chalk, NHMUK PV OR41105; A, schematized reconstruction of inner face from CT-scan; B, inner face of right otolith; C, inner face of left otolith (mirror imaged); D, dorsal view. E-G, Hoplopteryx causae (Nolf, 2003), Santonian, Spain, holotype, IRSNB P 6865 (refigured from Nolf (2003) with the permission of the author); E, inner face; F, anterior view; G, ventral view. H, Hoplopteryx oscitans (Nolf \& Stringer, 1996), Maastrichtian, Mississippi, USA, paratype IRSNB P 6157 (refigured from Nolf \& Stringer (1996) with the permission of the author), inner face. I-J, Hoplostethus crassispinus Kotlyar, 1980, Recent, $26^{\circ} 27^{\prime} \mathrm{N}, 127^{\circ} 36^{\prime} \mathrm{E}$, NSMT-P 114295; I, inner face; J, anterior view. K, Trachichthys australis Shaw, Recent, off Western Australia, coll. Schwarzhans (leg. WAM), inner face. All scale bars represent $1 \mathrm{~mm}$. 
distinctly turning upwards towards posterior. The resolution/ preservation does not allow recognition of the collicular crest of the lower margin of the caudal colliculum, which otherwise is very typical for many berycoid otoliths. Dorsal depression large. Ventral field poorly preserved and no ventral furrow discernable. Outer face slightly concave. Otolith very thin in lateral view, particularly its dorsal and ventral rims.

Remarks. The somewhat rugose surface and erosion along the otolith edges precludes correlation of the scanned in situ otolith of Hoplopteryx lewesiensis with otolithbased Cretaceous taxa on the species level. However, there are significant characters available that warrant a definition of the otoliths at the genus level (see above). This pattern is indeed shared by a number of otolith-based taxa, which were mostly identified as Trachichthyoidei incertae sedis. We now refer these species to Hoplopteryx: Hoplopteryx causae (Nolf, 2003) from the late Santonian of Spain (Fig. 11E-G), H. coffeesandensis (Nolf \& Dockery, 1990) from the Campanian of Mississippi, H. oscitans (Nolf \& Stringer, 1996) from the Maastrichtian of Mississippi (Fig. 11H), and H. supracretacea (Koken, 1891) from the Maastrichtian of Bavaria. The otoliths of two Recent Trachichthyidae are figured here for comparative purposes: Hoplostethus crassispinus Kotlyar, 1980 (Fig. 11I-J) and Trachichthys australis Shaw (Fig. 11K).

Order KURTIFORMES Betancur-R. et al. 2013 Family APOGONIDAE Günther, 1859

Genus APOGON Lacépède, 1801

Apogon macrolepis Storms, 1896

Figures $3 \mathrm{~A}, 12 \mathrm{~A}-\mathrm{E}$

Material. IRSNB 647, cotype, Wemmel Sands Member, Maldegem Formation, Neder-over-Hembeek, Belgium. Both otoliths preserved in situ, with no obvious replacement or dissolution.

Remarks. In situ otoliths were described from Apogon macrolepis Storms, 1896 from the Lutetian of Belgium by Taverne \& Nolf (1979) (Fig 12D, E). Our scans of an intact specimen show an identical structure to these mechanically isolated examples, and represent proof-ofconcept for the tomographic approach. The otoliths of A. macrolepis are characterized by an oval outline with a regularly and deeply curved ventral rim, a low dorsal rim without postdorsal angle, a projecting, well-rounded rostrum, and on the convex inner face a sulcus with a large, oval shaped, widened and shallow ostium and a short, somewhat deepened and straight cauda with a rounded tip.
Order SPARIFORMES Betancur-R et al. 2013 Family SPARIDAE Rafinesque, 1810

Genus DENTEX Cuvier, 1814

Dentex laekeniensis Van Beneden, 1872

Figures 3B, 12F-J

1896 Serranus wemmeliensis Storms, fig. 2.

1966 Plesioserranus wemmeliensis (Storms, 1896); Casier, fig. 36B.

Material. IRSNB 645, type of Plesioserranus wemmeliensis (Storms, 1896), Wemmel Sands Member, Maldegem Formation, Neder-over-Hembeek, Belgium. Both otoliths preserved in situ, with no obvious replacement or dissolution.

Remarks. On the basis of general aspects of skeletal morphology, this specimen was named as the type of Serranus wemmeliensis by Storms (1896). Casier (1966) subsequently assigned it to his new genus Plesioserranus. However, we find that the otoliths of this specimen closely match otoliths described in situ by Taverne \& Nolf (1979) (Fig. 12I-J) for the serranid Dentex laekeniensis, which also derives from the Wemmel Member. We conclude that Plesioserranus wemmeliensis is a junior synonym of Dentex laekeniensis. Otoliths of this species are characterized by a rather regular oval outline without prominent angles but a distinctly projecting rostrum, no excisura or antirostrum, a distinctly convex inner face with a long sulcus composed of a broad, rather short and somewhat deepened ostium and a long, narrow, moderately deep cauda, which is slightly flexed towards its tip which reaches close to the posterior rim of the otolith.

\section{Series PERCOMORPHA Rosen, 1973 Order \& Family INDET.}

Genus 'BRACHYGNATHUS' Agassiz, 1844

Remarks. Nomen nudum according to Casier (1966); preoccupied by Brachygnathus Perty, 1830 in Coleoptera. Brachygnathus tenuiceps Agassiz, 1844 was considered a nomen nudum in Casier's monograph of fishes of the London Clay (1966). In any case, he considered the 'type' specimen too poorly preserved to be identifiable even to generic level. A second specimen classified as B. tenuiceps was selected by Casier as holotype of Serranopsis londinensis Casier, 1966, which is regarded by Friedman et al. (2016) as Acanthomorpha incertae sedis. Brachygnathus Agassiz, 1844, if validated, would be preoccupied by Brachygnathus Perty, 1830 in Coleoptera. We therefore 

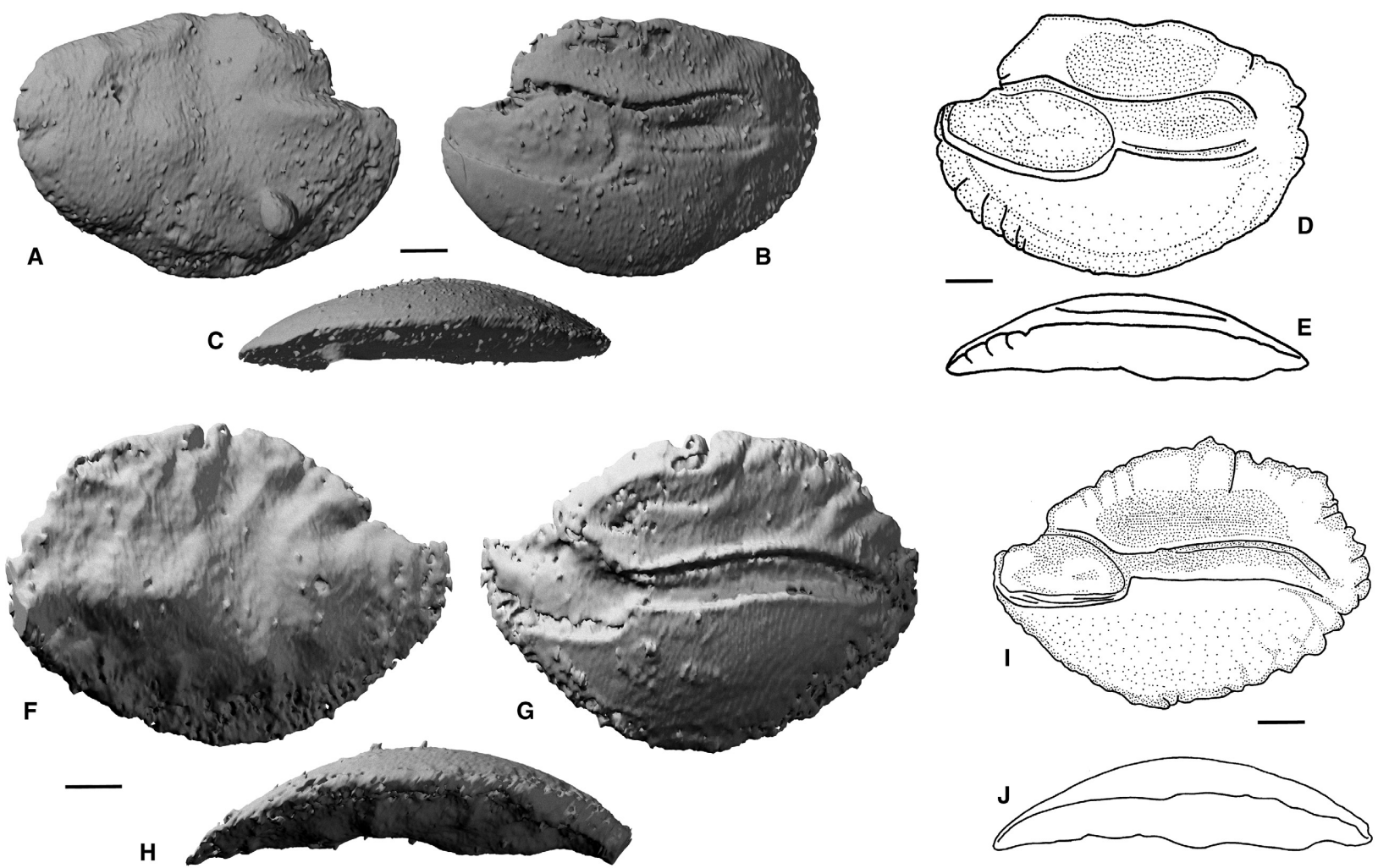

FIG. 12. A-E, Apogon macrolepis Storms, 1896, Eocene, Lutetian, Belgium; A-C (left otolith, mirror imaged), scanned in situ otolith, IRSNB 647; A, outer face; B, inner face; C, ventral view; D-E, mirror imaged, refigured from depiction of mechanically isolated example in Nolf (2013); D, inner face; E, ventral view. F-J, Dentex laekeniensis Van Beneden, 1872, Eocene, Lutetian, Belgium, IRSNB 645 (left otolith, mirror imaged); F-H, scanned in situ otolith; F, outer face; G, inner face; H, ventral view; I-J, mirror imaged (refigured from Nolf (2013) with the permission of the author); I, inner face, J, ventral view. All scale bars represent $1 \mathrm{~mm}$.

leave the generic assignment in quotation marks until the nomenclatural situation has been resolved.

\section{'Brachygnathus' tenuiceps Agassiz, 1844}

Figures 3E, 13A-C

?1957 Caesio bognoriensis Stinton, pl. 2 fig. 15. [otolithbased species]

?1977 Sebastodes bognoriensis (Stinton, 1957); Stinton, pl. 10 figs $24-26$.

Material. NHMUK PV P643, London Clay Formation, Sheppey, UK. Only the left otolith is preserved in situ.

Description. In contrast to most other examples from the London Clay Formation described here, the otolith of 'Brachygnathus' has not been replaced with a dense material. The otolith is about $13.2 \mathrm{~mm}$ length with strongly rugose surface and edged margins. The following description is therefore reduced to relatively few discernable features. $\mathrm{OL}: \mathrm{OH}=2.1 ; \mathrm{OH}: \mathrm{OT}=2.8$. Otolith shape elongate, with projecting, inferior rostrum and angular posterior tip. Dorsal and ventral rims shallow, irregularly bent. Anterior rim possibly with excisura.
Inner face distinctly convex with sulcus positioned along axis and not inclined. Ostium somewhat shorter than cauda, but considerably wider and anteriorly open. Cauda very narrow, perfectly straight, moderately deep and terminating at considerable distance from posterior tip of otolith. No further details visible on inner face.

Remarks. The general outline of the otolith of 'Brachygnathus', combined with proportions of the sulcus, and the short, narrow and completely straight cauda suggest a correspondence with the London Clay otolith taxon originally described as Caesio bognoriensis Stinton, 1957, and later revised to Sebastodes bognoriensis (Stinton, 1977). Nolf (2013) rejected the species based on the strongly eroded holotype, but Stinton (1977) figured some wellpreserved specimens, which undoubtedly represent the same species (Fig. 13D). These otoliths are smaller than the in situ otolith (up to $5 \mathrm{~mm}$ length) and exhibit very similar otolith and sulcus proportions and outline, but also show a dorsally slightly widened caudal tip. Because of this, and the rather poor model of the in situ otolith, we refrain from a definite correlation of the skeleton and the otolith-based taxon. Unfortunately, the skeletal 


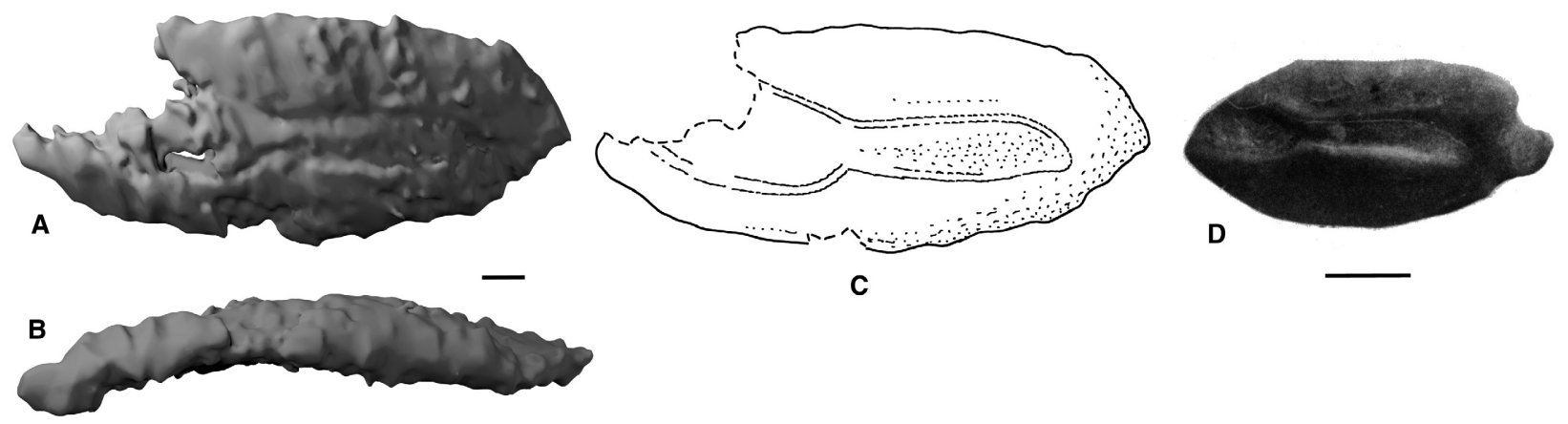

FIG. 13. A-C, scanned in situ otolith of 'Brachygnathus' tenuiceps, Eocene, Ypresian, London Clay, NHMUK PV P643 (left otolith, mirror imaged); A, inner face; B, ventral view; C, schematized reconstruction of inner face from $\mu$ CT scan. D, otolith-based species 'Brachygnathus' bognoriensis (Stinton, 1957) [originally described as Caesio bognoriensis], Eocene, Ypresian, London Clay, NHMUK PV P58608 (mirror imaged; refigured from Stinton (1978); (C) The Palaeontographical Society, reproduced with permission).

remains of 'Brachygnathus' are very poorly preserved, not allowing us to comment further on its possible systematic placement based on osteological features.

\section{?EURYPTERYGII Rosen, 1973 INCERTAE SEDIS}

Figure 3K Material. NHMUK PV P52492, Gault Clay Formation,
Naccolt, Kent, UK.

Description. A pair of small otoliths of about $2.5 \mathrm{~mm}$ length with a poorly discernible surface morphology and severe erosion along the edges, probably a result of crystallization or other precipitation of minerals in the void of the dissolved otolith. OL: $\mathrm{OH}$ about 1.5; OH:OT about 2.5. The otoliths are oval in outline and rather robust, but no further details are apparent due to the severe erosion along its margins. Likewise, very little surface detail is visible except for a large, slightly upward-oriented shallow depression connecting to the anterior-dorsal rim of the otoliths, which could represent the ostium. Unfortunately, this otolith morphology cannot be tied to any isolated otoliths. It should be mentioned, however, that similar small, robust, oval otoliths are known from isolated Late Cretaceous examples interpreted as apogonid percomorphs by Nolf \& Stringer (1996) and Myctophiformes incertae sedis by Schwarzhans (2010).

Remarks. Both otoliths preserved in situ, partially as void and partially as replacement with a dense mineral, probably pyrite. The specimen studied here has not been subjected to detailed anatomical description, and has not formally been assigned to a named taxon. The specimen label identifies it as Ctentothrissa, but this attribution is questioned based on the presence of roofed posttemporal fossae (see also note accompanying specimen left by Niels Bonde and dated January 1975, who made comparisons with the aulopiform Aulopus). Additionally, the specimen has ossified sclerotics and narrow, unornamented frontals, neither of which are present in Ctenothrissa. In the absence of more detailed information on the specimen, we instead choose to leave it in open nomenclature as a possible eurypterygian.

Acknowledgements. The authors thank Farah Ahmed, Emma Bernard, Zerina Johanson, Rebecca Summerfield, and Dan Sykes for access to the collections and assistance with scanning at the Natural History Museum, London. We also thank Annelise Folie at the Royal Belgian Institute of Natural Sciences and Reinier van Zelst at the Naturalis Biodiversity Centre who facilitated the loan of specimens for scanning and study. Donald Davense provided photographs of the holocentrid from the Hornerstown Formation. We are grateful to Dirk Nolf for allowing to use certain of his drawings. Giorgio Carnevale, Jürgen Kriwet and Chien-Hsiang Lin provided helpful reviews that, along with editorial assistance from Sally Thomas, substantially improved this contribution. This research was supported by a NERC studentship to $\mathrm{HB}$ on the DTP Environmental Research (NE/ L0021612/1), a Leverhulme Project Grant (RPG-2012-658) and Leverhulme Prize (PLP-2012-130), both to MF.

\section{DATA ARCHIVING STATEMENT}

Data for this study are available in the Dryad Digital Repository: https://doi.org/10.5061/dryad.72rh2

Editor. Imran Rahman

\section{REFERENCES}

AGASSIZ, L. 1833-1844. Recherches sur les poissons fossiles, 5 vols. Petitpierre, Neuchâtel.

1845. Report on the fossil fishes of the London Clay. Report of the British Association, London, 1844, 279-310.

APPLEGATE, S. P. 1996. An overview of the Cretaceous fishes of the quarries near Tepexi de Rodríguez, Puebla, México. 529-538. In ARRARIA, G. and VIOHL, G. (eds). Mesozoic 
fishes: systematics and paleoecology. Friedrich Pfeil, Munich, 576 pp.

ARRATIA, G. and TISCHLINGER, H. 2010. The first record of Late Jurassic crossognathiform fishes from Europe and their phylogenetic importance for teleostean phylogeny. Fossil Record, 13, 317-341.

BECKETT, H. T. and FRIEDMAN, M. 2016. The one that got away from Smith Woodward: cranial anatomy of Micrornatus (Acanthomorpha: Scombridae) revealed using computed microtomography. Geological Society, London, Special Publications, 430, 337-353.

- GILES, S. and FRIEDMAN, M. 2017. Comparative anatomy of the gill skeleton of fossil Aulopiformes (Teleostei: Eurypterygii). Journal of Systematic Palaeontology, 22 November, 1-25. https://doi.org/10.1080/14772019.2017.1387184

BELLWOOD, D. R., GOATLEY, C. H., BELLWOOD, O., DELBARRE, D. J. and FRIEDMAN, M. 2015. The rise of jaw protrusion in spiny-rayed fishes closes the gap on elusive prey. Current Biology, 25, 2696-2700.

BETANCUR-R, R., BROUGHTON, R. E., WILEY, E. O., CARPENTER, K., LÓPEZ, J. A., LI, C., HOLCROFT, N. I., ARCILA, D., SANCIANGCO, M., CURETON, J. C., ZHANG, F., BUSER, T., CAMPBELL, M. A., BAllesteros, J. A., ROA-VARON, A., Willis, S., BORDEN, W. C., ROWLEY, T., REBEAU, P. C., HOUGH, D. J., LU, G., GRANDE, T., ARRATIA, G. and ORTÍ, G. 2013. The tree of live and a new classification of bony fishes. Plos Currents Tree of Life, 18 April, 1-45. https://doi.org/10.1371/currents.tol.53ba26640df0ccaee75bb $165 \mathrm{c} 8 \mathrm{c} 26288$

BLEEKER, P. 1853. Vierde bijdrage tot de kennis der ichthyologische fauna van Amboina. Natuurkundig Tijdschrift Voor Nederlandsch Indië, 5, 317-352.

1856. Beschrijvingen van nieuwe of weinig bekende vischsoorten van Manado en Makassar, grootendeels verzameld op eene reis naar den Molukschen Archipel in het gevolg van den Gouverneur Generaal Duymaer van Twist. Acta Societatis Regiae Scientiarum Indo-Neêrlandicae, 1, 1-80.

BONAPARTE, C. L. 1833. Iconografia della fauna italica per le quattro classi degli animali vertebrati. Tomo III. Pesci. Salviucci, Rome.

BOUlengER, G. A. 1914. Mission Stappers au TanganyikaMoero. Diagnoses de poissons nouveaux. I. Acanthoptérygiens, Opisthomes, Cyprinodontes. Revue de Zoologie Africaine, 3, 442-447.

BRONN, H. 1830. Über zwei fossile Fischarten: Cyprinus coryphaenoides und Tetragonolepis semicinctus aus dem Gryphitenkalke bei Donaueschingen. Jahrbuch für Mineralogie, Geognosie und Petrefaktenkunde, 1, 13-40.

CARNEVALE, G. and JOHNSON, G. D. 2015. A Cretaceous cusk-eel (Teleostei, Ophidiiformes) from Italy and the Mesozoic diversification of percomorph fishes. Copeia, 103, 771-791.

—— MARRAMÁ, G. and BANNIKOV, A. F. 2017. A reappraisal of the Eocene priacanthid fish Pristigenys substriata (Blainville, 1818) from Monte Bolca, Italy. Journal of Paleontology, 91, 554-565.

CARPENTER, K. 2008. Vertebrate biostratigraphy of the Smoky Hill Chalk (Niobrara Formation) and the Sharon
Springs Member (Pierre Shale). 421-437. In HARRIES, P. J. (ed.) High-resolution approaches in stratigraphic paleontology. Springer, $470 \mathrm{pp}$.

CASIER, E. 1946. La faune ichthyologique de l'Yprésien de la Belgique. Mémoires du Musée Royal d'Histoire Naturelle de Belgique, 104, 1-267.

1966. Faune ichthyologique du London Clay. Trustees of the British Museum (Natural History), London, 403 pp.

CHANG, M.-M. and JIN, F. 1996. Mesozoic fish faunas of China. 461-478. In ARRARIA, G. and VIOHL, G. (eds). Mesozoic fishes: systematics and paleoecology. Friedrich Pfeil, Munich, 576 pp.

CHERNS, L. and WRIGHT, V. P. 2000. Missing molluscs as evidence of large-scale, early skeletal aragonite dissolution in a Silurian sea. Geology, 28, 791-794.

CLODE, D. 2015. Prehistoric marine life in Australia's inland sea. Museum Victoria, Melbourne, $84 \mathrm{pp}$.

CLOSE, R., JOHANSON, Z., TYLER, J. C., HARRINGTON, R. C. and FRIEDMAN, M. 2016. Mosaicism in a new Eocene pufferfish highlights rapid morphological innovation near the origin of crown tetraodontiforms. Palaeontology, 59, 499-514.

Clouter, F. C., MitChell, T., RAYNeR, D. and RAYNER, M. 2000. London Clay fossils of the Isle of Sheppey. Medway Lapidary \& Mineral Society, Rochester, UK, 100 pp.

COHEN, D. M. 1984. Gadiformes: overview. 259-265. In MOSER, H. G. (ed.) Ontogeny and systematics of fishes. American Society of Ichthyologists and Herpetologists, Special Publication, 1.

COLLINS ON, M. E. 1983. Fossil plants of the London Clay. The Palaeontological Association, Field Guides to Fossils, 1, 121 pp.

COPE, E. D. 1871. Contribution to the ichthyology of the Lesser Antilles. Transactions of the American Philosophical Society, 14, 445-483.

CUVIER, G. 1814. Observations et recherches critiques sur différens poissons de la Méditerranée et, à leur occasion, sur des poissons des autres mers plus ou moins liés avec eux. [In a report by A. G. DESMAREST] Bulletin des Sciences, par la Société Philomathique de Paris, 3, 80-92.

DAVIES, T. G., RAHMAN, I. A., LAUTENSCHLAGER, S., CUNNINGHAM, J. A., ASHER, R. J., BARRETT, P. M., BATES, K. T., BENGTSON, S., BENSON, R. B., BOYER, D. M., BRAGA, J., BRIGHT, J. A., CLAESSENS, L. P. A. M., COX, P. G., DONG, X.-P., EVANS, A. R., FALKINGHAM, P. L., FRIEDMAN, M., GARWOOD, R. J., GOSWAMI, A., HUTCHINSON, J. R., JEFFERY, N. S., JOHANSON, Z., LEBRUN, R., MARTINEZ-PÉREZ, C., MARUGÁN-LOBÓN, J., O’HIGGINS, P. M., METSCHER, B., ORLIAC, M., ROWE, T. B., RÜCKLIN, M., SÁNCHEZ-VILlAGRA, M. R., SHUBIN, N. H., SMITH, S. Y., STARCK, J. M., STRINGER, C., SUMMERS, A. P., SUTTON, M. D., WALSH, S. A., WEISBECKER, V., WITMER, L. M., WROE, S., YIN, Z., RAYFIELD, E. J. and DONOGHUE, P. C. J. 2017. Open data and digital morphology. Proceedings of the Royal Society B, 284, 20170194.

DAVIS, M. P. and FIELITZ, C. 2010. Estimating diversion times of lizardfishes and their allies (Euteleostei: 
Aulopiformes) and the timing of deep-sea adaptations. Molecular Phylogenetics \& Evolution, 57, 1194-1208.

DE GEYTER, G., DE MAN, E., HERMAN, J., JACOBS, P., MOORKENS, T., STEURBAUT, E. and VANDENBERGHE, N. 2006. Disused Paleogene regional stages from Belgium: Montian, Heersian, Landenian, Paniselian, Bruxellian, Laekenian, Ledian, Wemmelian and Tongrian. Geologica Belgica, 9, 203-213.

DELSATE, D. 1997. Actinoptérygens du Toarcien inférieur du Grand Duché de Luxembourg: présence de Leptolepis normandica Nybelin 1962 (Teleostéen) avec otolithes in situ. Travaux Scientifiques du Musée nationale D'Histoire naturelle de Luxembourg, 27, 105-129.

DIXON, F. 1850. The geology and fossils of the Tertiary and Cretaceous formations of Sussex. Longmans, Brown, Green \& Longmans, London.

DORNBURG, A., FRIEDMAN, M. and NEAR, T. J. 2015. Phylogenetic analysis of molecular and morphological data highlights uncertainty in the relationships of fossil and living species of Elopomorpha (Actinopterygii: Teleostei). Molecular Phylogenetics \& Evolution, 89, 205-218.

— TOWNSEND, J. P., BROOKS, W., SPRIGGS, E., EYTAN, R. I., MOORE, J. A., WAINWRIGHT, P. C., LEMMON, A., LEMMON, E. M. and NEAR, T. J. 2017. New insights on the sister lineage of percomorph fishes with an anchored hybrid enrichment dataset. Molecular Phylogenetics \& Evolution, 110, 27-38.

EGE, V. 1933. On some new fishes of the families Sudidae and Stomiatidae. Preliminary note. Videnskabelige Meddelelser fra Dansk Naturhistorisk Forening, 94, 223-236.

ENDO, H. 2002. Phylogeny of the order Gadiformes (Teleostei, Paracanthopterygii). Memoirs of the Graduate School of Fisheries Sciences, Hokkaido University, 49, 75-149.

FEDOTOV, V. F. 1976. Gadidae of the palaeogene-neogene from the U.S.S.R. Transactions of the Paleontological Institute of the Academy of Sciences USSR, 157, 5-83. [English translation]

_ and BANNIKOV, A. F. 1989. On phylogenetic relationships of fossil Gadidae. Papers on the Systematics of Gadiform Fishes, Natural History Museum of Los Angeles County, Science Series, 32, 187-195.

FOREY, P. L. 1973. A revision of the elopiform fishes, fossil and recent. Bulletin of the British Museum (Natural History), Geology, Supplement, 10, 1-222.

— and LONGBOTTOM, A. 2010. Bony fishes. 261-269. In YOUNG, J. R., GALE, A. S., KNIGHT, R. I. and SMITH, A. B. (eds). Fossils of the Gault Clay. Palaeontological Association, Field Guides to Fossils, 12,342 pp.

FORIR, H. 1887. Contributions à l'étude du système crétacé de la Belgique. I. Sur quelques poissons et crustacés nouveaux ou peu connus. Annales de la Société Géologique de Belgique, 14, $37-42$.

FRASER, T. H. 1972. Comparative osteology of the shallow water cardinal fishes (Perciformes: Apogonidae) with reference to the systematics and evolution of the family. Ichthyological Bulletin of the J. L. B. Smith Institute of Ichthyology, 34, 1-105.

FRIEDMAN, M. 2008. The evolutionary origin of flatfish asymmetry. Nature, 454, 209-212.
- 2009. Ecomorphological selectivity among marine teleost fishes during the end-Cretaceous extinction. Proceedings of the National Academy of Sciences, 106, 5218-5223.

_ 2010. Explosive morphological diversification of spinyfinned teleost fishes in the aftermath of the end-Cretaceous extinction. Proceedings of the Royal Society B, 277, 20092177.

— 2012. Ray-finned fishes (Osteichthyes, Actinopterygii) from the type Maastrichtian, the Netherlands and Belgium. Scripta Geologica Special Issue, 8, 113-142.

- 2015. The early evolution of ray-finned fishes. Palaeontology, 58, 213-228.

- and GILES, S. 2016. Actinopterygians: the ray-finned fishes - an explosion of diversity. 17-49. In CLACK, J. A., FAY, R. R. and POPPER, A. N. (eds). Evolution of the vertebrate ear: evidence from the fossil record. Springer, $355 \mathrm{pp}$.

— BECKETT, H. T., CLOSE, R. A. and JOHANSON, Z. 2016. The English chalk and London Clay: two remarkable British bony fish Lagerstätten. Geological Society, London, Special Publications, 430, 165-200.

FRIZZELL, D. L. 1965. Otolith-based genera and lineages of fossil bonefishes (Clupeiformes, Albulidae). Senckenbergiana Lethaea, 46a, 85-110.

GALE, A. S. and KENNEDY, W. J. 2002. Introduction. 1-26. In SMITH, A. B. and BATTEN, D. J. (eds). Fossils of the chalk. 2nd edn. Palaeontological Association, Field Guide to Fossils, 2, 374 pp.

— and OWEN, H. G. 2010. Introduction to the Gault. 1-15. In YOUNG, J. R., GALE, A. S., KNIGHT, R. I. and SMITH, A. B. (eds). Fossils of the Gault Clay. Palaeontological Association, Field Guides to Fossils, 12, 342 pp.

GAYET, M. 1982. Essai de definition des relations phylogénétiques des Holocentroidea nov. et des Trachichthyoidea nov. (Pisces, Acanthopterygii, Béryciformes). Bulletin du Museum national D'Histoire naturelle, Paris, 4e Série, Section C, 4, 21-41.

GOODRICH, E. S. 1909. Vertebrata Craniata. Part 9. First faciscle: cyclosomes and fishes. 1-518. In LANKESTER, R. (ed.) A treatise on zoology. A. \& C. Black, London.

GOODY, P. C. 1969. The relationships of certain Upper Cretaceous teleosts with special reference to the myctophoids. Bulletin of the British Museum (Natural History): Geology, Supplement, 7, 1-255.

GRANDE, L. 2010. An empirical synthetic pattern study of gars (Lepisosteiformes) and closely related species, based mostly on skeletal anatomy. The resurrection of Holostei. Copeia, 10, 1-871.

— and CHATTERJEE, S. 1987. New Cretaceous fish fossils from Seymour Island, Antarctic Peninsula. Palaeontology, 30, 829-883.

GRANDSTAFF, B. S. and PARRIS, D. C. 2016. A new species of Hoplopteryx from the Carslile Formation (Cretaceous) of South Dakota. Proceedings of the South Dakota Academy of Science, 95, 73-84.

GUINOT, G. and CAVIN, L. 2015. 'Fish' (Actinopterygii and Elasmobranchii) diversification patterns through deep time. Biological Reviews, 91, 950-981.

GÜNTHER, A. 1859. Catalogue of the fishes in the British Museum. Catalogue of the acanthopterygian fishes in the collection of the British Museum. Gasterosteidae, Berycidae, Percidae, 
Aphredoderidae, Pristipomatidae, Mullidae, Sparidae. British Museum (Natural History), 524 pp.

- 1878. Preliminary notices of deep-sea fishes collected during the voyage of H. M. S. 'Challenger'. Annals \& Magazine of Natural History (Series 5), 2 (7/8/9), 17-28, 179-187, 248-251.

1887. Report on the deep-sea fishes collected by H. M. S. Challenger during the years 1873-76. Report on the Scientific Results of the Voyage of H. M. S. Challenger, 22, 1-268.

HIYAMA, Y. 1940. Descriptions of two new species of fish, Raja tobitukai and Chlorophthalmus acutifrons. Japanese Journal of Zoology, 9, 169-173.

JAGT, J. W. M. and JAGT-YAZYKOVA, E. A. 2012. Stratigraphy of the type Maastrichtian - a synthesis. Scripta Geologica Special Issue, 8, 5-32.

JORDAN, D. S. 1905. A guide to the study of fishes. Henry Holt \& Sons, New York, 589 pp.

— 1923. A classification of fishes including families and genera as far as known. Stanford University Publications, University Series, Biological Sciences, 3, 77-243.

KENNEDY, W. J. and COBBAN, W. A. 1996. Maastrichtian ammonites from the Hornerstown Formation in New Jersey. Journal of Paleontology, 70, 798-804.

KOCH, R. C. and OLSSON, R. K. 1977. Dinoflagellate and planktonic foraminiferal biostratigraphy of the uppermost Cretaceous of New Jersey. Journal of Paleontology, 51, 480491.

KOKEN, E. 1884. Über Fisch-Otolithen, insbesondere über diejenigen der norddeutschen Oligocän-Ablagerungen. Zeitschrift der Deutschen Geologischen Gesellschaft, 36, 500-565.

— 1891. Otolithen. 37-40. In BÖHM, J. (ed.) Die Kreidebildungen des Fürbergs und Sulzbergs bei Siegsdorf in Oberbayern. Palaeontographica, 38.

KOTLYAR, A. N. 1980. A new species of the genus Hoplostethus (Trachichthyidae, Beryciformes) from the north-west Pacific. Zoologicheskii Zhurnal, 59, 1054-1059. [in Russian]

— 1996. Beryciform fishes of the world oceans. VNIRO Publishing, Moscow, 367 pp. [in Russian]

KREFFT, G. and MAUL, G. E. 1955. Notosudis lepida n. sp. (Iniomi, Notosudidae), eine neue Fischart aus dem östlichen Nord-Atlantik. Archiv für Fischereiwissenschaft, 6, 305-316.

KRØYER, H. N. 1868. To nye fiske fo den danske fauna. Tidsskrift for Fiskeri/Udgivet af H. V. Fiedler og Arthur Ferrersen, 2, 70-71.

KRUIZINGA, P. 1924. †Apateodus corneti (For.) in the Senonian beds of the southern part of Limburg (Netherlands). Proceedings of the Science Section of the Koninklijke Nederlandse Akademie van Wetenschappen, 27, 293-312.

LACÉP ÈDE, B. G. E. 1801. Histoire naturelle des poissons. 3. Plassan, Paris 558 pp.

LERICHE, M. 1905. Les poissons éocènes de la Belgique. Mémoires du Musée Royal D’Histoire Naturelle de Belgique, 1e Série, 3, 51-288.

LLOYD, G. T. and FRIEDMAN, M. 2013. A survey of palaeontological sampling biases in fishes based on the Phanerozoic record of Great Britain. Palaeogeography, Palaeoclimatology, Palaeoecology, 372, 5-17.

LOMBARTE, A., CHIC, Ò., PARISI-BARADAD, V., OLIVELlA, R., PIERA, J. and GARCIA-LADONA, E.
2006. A web-based environment from shape analysis of fish otoliths. The AFORO database. Scientia Marina, 70, 147-152.

LONG, J. A. and TRINAJSTIC, K. 2010. The Late Devonian Gogo Formation Lägerstatte [sic] of Western Australia: exceptional early vertebrate preservation and diversity. Annual Review of Earth \& Planetary Sciences, 38, 255-279.

LONGBOTTOM, A. E. and PATtERSON, C. 2002. Fishes. 296-324. In SMITH, A. B. and BATTEN, D. J. (eds). Fossils of the chalk. 2nd edn. Palaeontological Association, Field Guides to Fossils, 2, 374 pp.

LOWE, R. T. 1833. Description of Alepisaurus, a new genus of fishes. Proceedings of the Zoological Society of London, 1833, 104.

— 1839. A supplement to a synopsis of the fishes of Madeira. Proceedings of the Zoological Society of London, 1839, 76-92.

MAISEY, J. G. 1991. Santana fossils: an illustrated atlas. T.F.H Publications, Neptune City, NJ, 459 pp.

MANTELL, G. A. 1822. The fossils of the South Downs: or illustrations of the geology of Sussex. Lumpton Rolfe, London.

MEAD, G. W. 1958. Three new species of archibenthic iniomous fishes from the western North Atlantic. Journal of the Washington Academy of Science, 48, 362-372.

MILLER, H. W. Jr 1958. An elopid fish from the Codell Sandstone (Cretaceous) of Kansas and the depositional environment of the sandstone. Transactions of the Kansas Academy of Science, 61, 213-215.

MONSCH, K. A. 2005. Revision of the scombroid fishes from the Cenozoic of England. Transactions of the Royal Society of Edinburgh: Earth Sciences, 95, 445-489.

— and BANNIKOV, A. F. 2011. New taxonomic synopses and revision of the scombroid fishes (Scombroidei, Perciformes), including billfishes, from the Cenozoic of territories of the former USSR. Earth \& Environmental Science Transactions of the Royal Society of Edinburgh, 102, 253-300.

MOORE, J. A. 1993. Phylogeny of the Trachichthyiformes (Teleostei: Percomorpha). Bulletin of Marine Science, 52, 114136.

MÜLLER, J. 1848. Fossile Fische. 261-263. In VON MIDDENDORFF, A. T. Reise in den äussersten norden und osten Sibiriens während der Jahre 1843 und 1844. Vol. 1, Buchdrukerei der Kaiserlichen Akademie der Wissenschaften, St Petersburg, Russia.

NEAR, T. J., DORNBURG, A., EYTAN, R. I., KECK, B. P., SMITH, W. L., KUHN, K. L., MOORE, J. A., PRICE, S. A., BURBRINK, F. T., FRIEDMAN, M. and WAINWRIGHT, P. C. 2013. Phylogeny and tempo of diversification in the superradiation of spiny-rayed fishes. Proceedings of the National Academy of Sciences, 110, 1273812743.

NELSON, J. S., GRANDE, T. C. and WILSON, M. V. H. 2016. Fishes of the world. 5th edn. John Wiley \& Sons, 707 pp. NEWBREY, M. G. and KONISHI, T. 2015. A new lizardfish (Teleostei, Aulopiformes) from the Late Cretaceous Bearpaw Formation of Alberta, Canada, with a revised diagnosis of $\dagger$ Apateodus (Aulopiformes, Ichthyotringoidei). Journal of Vertebrate Paleontology, 35, e918042.

NOLF, D. 1995. Studies on fossil otoliths - The state of the art. 513-544. In SECOR, D. H., DEAN, J. M. and 
CAMPANA, S. E. (eds). Recent developments in fish and otolith research. University of South Carolina Press, Columbia, SC, $735 \mathrm{pp}$.

_ 2003. Fish otoliths from the Santonian of the Pyrenean realm, and an overview of all otolith-documented North Atlantic Late Cretaceous teleosts. Bulletin de l'Institut royal des Sciences naturelles de Belgique, Sciences de la Terre, 73, 155173.

- 2004. Otolithes de poissons aptiens du Maestrazgo (province de Castellon, Espagne Orientale). Bulletin de L'Institut royal des Sciences naturelles de Belgique, Sciences de la Terre, 74, 101-120.

— 2010. Otoliths. 270-274. In YOUNG, J. R., GALE, A. S., KNIGHT, R. I. and SMITH, A. B. (eds). Fossils of the Gault Clay. Palaeontological Association, Field Guides to Fossils, 12, $342 \mathrm{pp}$.

— 2013. The diversity of fish otoliths, past and present. Royal Belgian Institute of Natural Sciences, Brussels, 222 pp.

— 2016. Otoliths of Cenomanian fishes in the Ballon Marl (France). The earliest fossil record of perciform fishes. Bulletin D'Information des Géologiques du Bassin Parisien, 53, 14-20.

— and DOCKERY, D. T. 1990. Fish otoliths from the Coffee Sand (Campanian of Northeastern Mississippi). Mississippi Geology, 10, 1-14.

— and STRINGER, G. L. 1996. Cretaceous fish otoliths - a synthesis of the North American record. 433-459. In ARRATIA, G. and VIOHL, G. (eds). Mesozoic fishes: systematics and paleoecology. Friedrich Pfeil, Munich, 576 pp.

NOVITSKAYA, L. I. 1961. Rod Palaeogadus treskovye iz khadumskovo gorizonta Kavkaza. Paleontologicheskij Zhurnal, 4, 120-130. [in Russian]

NYBELIN, O. 1962. Preliminary note on two species previously named Leptolepis bronni Agassiz. Arkiv för Zoologi, 15, 303-306.

PALMER, T. J., HUdSON, J. D. and WILSON, M. A. 1988. Palaeoecological evidence for early aragonite dissolution in ancient calcite seas. Nature, 335, 809-810.

PARR, A. E. 1928. Deepsea fishes of the order Iniomi from the waters around the Bahama and Bermuda islands. With annotated keys to the Sudididae, Myctophidae, Scopelarchidae, Evermannellidae, Omosudidae, Cetomimidae and Rondeletidae of the world. (Scientific results of the third oceanographic expedition of the "Pawnee" 1927). Bulletin of the Bingham Oceanographic Collection Yale University, 3, 1-193.

PATTERSON, C. 1964. A review of Mesozoic acanthopterygians fishes, with special reference to those of the English Chalk. Philosophical Transactions of the Royal Society of London $B, 247,213-482$.

- 1977. The contribution of paleontology to teleostean phylogeny. 579-643. In HECHT, M. K., GOODY, P. C. and HECHT, B. M. (eds). Major patterns in vertebrate evolution. Plenum Press, 908 pp.

- 1993a. An overview of the early fossil record of acanthomorphs. Bulletin of Marine Science, 52, 29-59.

— 1993b. Osteichthyes: Teleostei. 621-656. In BENTON, M. J. (ed.) The fossil record 2. Chapman \& Hall, 845 pp.

— and ROSEN, D. E. 1977. Review of the ichthyodectiform and other Mesozoic teleost fishes and the theory and practice of classifying fossils. Bulletin of the American Museum of Natural History, 158, 83-172.

— and SMITH, A. B. 1987. Is the periodicity of extinctions a taxonomic artefact? Nature, 330, 248-251.

— 1989. Periodicity in extinction: the role of systematics. Ecology, 70, 802-811.

PERTY, J. A. M. 1830. Insecta Brasiliensia. In SPIX, J. and MARTIUS, C. (eds). Delectus animalium articulatorum, quae in itinere per Brasiliam annis MDCCCXVII-MDCCCXX jussu et auspiciis Maximilliani Josephi I. Bavariae regis augustissimi peracto. Fridrich Fleischer, Washington, 60 pp.

POYATO-ARIZA, F. J. and MARTÍN-ABAD, H. 2016. Osteichthyan fishes. 114-132. In POYATO-ARIZA, F. J. and BUSCALIONI, A. D. (eds). Las Hoyas: a Cretaceous Wetland. Friedrich Pfeil, Munich, 262 pp.

P ǨIKRYL, T., SCHWARZHANS, W. and KOVALCHUK, O. 2017. Lanternfishes (Myctophidae) with otoliths in situ from the Early Oligocene of the Eastern Paratethys (western Ukraine). Neues Jahrbuch für Geologie und Paläontologie, Abhandlungen, 285, 213-225.

PROKOFIEV, A. M. 2002. A new genus of cutlassfish from the Upper Paleocene of Turkmenistan (Scombroidei: Trichiuroidea). Zoosystematica Rossica, 11, 229-233.

RAFINESQUE, C. S. 1810. Caratteri di alcuni nuovi generi e nuove specie di animali e piante della Sicilia, con varie osservazioni sopra $i$ medisimi. Sanfilippo, Palermo, 69 pp.

RAYNER, D., MITCHELL, T., RAYNER, M. and CLOUTER, F. 2009. London Clay fossils of Kent and Essex. Medway Lapidary \& Mineral Society, Rochester, UK, 228 pp.

REGAN, C. T. 1909. The classification of teleostean fishes. The Annals \& Magazine of Natural History, 8, 75-86.

_ 1925. The fishes of the genus Gigantura, A. Brauer; based on specimens collected in the Atlantic by the "Dana" Expeditions, 1920-22. Annals \& Magazine of Natural History, 15, 53-59.

REIS, M. 1909. Die Binnenfauna der Fischschiefer in Transbaikalien. Recherches Géologiques et Minières le Long du Chemin de fer de Sibérie, 29, 1-68.

RIVATON, J. and BOURRET, P. 1999. Les otolithes des poissons de l'Indo-Pacificque. Documents Scientifques et Techniques, Institut de Recherche Pour le Dévelopment, Nouméa, 2, 1-378.

ROFEN, R. R. 1963. Diagnoses of new species and a new genus of alepisauroid fishes of the family Scopelarchidae. Aquatica, $3,1-4$.

ROSEN, D. E. 1973. Interrelationships of higher euteleostean fishes. 297-513. In GREENWOOD, P. H., MILES, R. S. and PATTERSON, C. (eds). Interrelationships of fishes. Academic Press, 536 pp.

SCHIØLER, P., BRINKHUIS, H., RONCAGLIA, L. and WILSON, G. J. 1997. Dinoflagellate biostratigraphy and sequence stratigraphy of the type Maastrichtian (Upper Cretaceous), ENCI Quarry, The Netherlands. Marine Micropaleontology, 31, 65-95.

SCHUBERT, R. J. 1906. Die Fischotolithen des österreichischungarischen Tertiärs, III. Jahrbuch der Kaiserlich-Königlichen Geologischen Reichsanstalt, Wien, 56, 623-706.

— 1916. Obereozäne Otolithen vom Barton Cliff bei Christchurch (Hampshire). Jahrbuch der Kaiserlich-Königlichen Geologischen Reichsanstalt, Wien, 65, 277-288. 
SCHWARZHANS, W. 1980. Die tertiäre Teleosteer-Fauna Neuseelands, rekonstruiert anhand von Otolithen. Berliner Geowissenschaftliche Abhandlungen, Reihe A, 26, 1-211.

— 1985. Tertiäre Otolithen aus South Australia und Victoria (Australien). Palaeo Ichthyologica, 3, 1-60.

- 2003. Fish otoliths from the Paleocene of Denmark. Geological Survey of Denmark \& Greenland Bulletin, 2, 1-94.

2004. Fish otoliths from the Paleocene (Selandian) of West Greenland. Meddelser om Grønland, 42, 1-32.

_ 2007a. Otoliths from casts from the Eocene Lillebælt Clay Formation of Trelde Næs near Fredericia (Denmark), with remarks on the diet of stomatopods. Neues Jahrbuch für Geologie und Paläontologie, Abhandlungen, 246, 69-81.

— 2007b. The otoliths from the Eocene of Osteroden near Bramsche, north-western Germany. Neues Jahrbuch für Geologie und Paläontologie, Abhandlungen, 244, 299-369.

— 2010. Otolithen aus den Gerhartsreiter Schichten (Oberkreide: Maastricht) des Gerhartsreiter Grabens (Oberbayern). Palaeo Ichthyologica, 4, 1-100.

— 2012. Fish otoliths from the Paleocene of Kressenberg, Bavaria, and Kroisbach, Austria. Palaeo Ichthyologica, 12, 188.

_ 2014. Synomization of the skeleton-based Palimphemus anceps Kner, 1862 and the otolith-based Colliolus sculptus (Koken, 1891) (Gadidae; Teleostei). Cainozoic Research, 14, 916.

- and BRATISHKO, A. 2011. The otoliths from the middle Paleocene of Luzanivka (Cherkasy district, Ukraine). Neues Jahrbuch für Geologie und Paläontologie, Abhandlungen, 261, 83-110.

_ SCOFIELD, R. P., TENNYSON, A. J. D., WORTHY, J. P. and WORTHY, T. H. 2012. Fish remains, mostly otoliths, from the non-marine Early Miocene of Otago, New Zealand. Acta Paleontologica Polonica, 57, 319-350.

— CARNEVALE, G., BANNIKOV, A. F., JAPUNDŽIĆ, S. and BRADIĆ, K. 2017a. Otoliths in situ from Sarmatian (Middle Miocene) fishes of the Paratethys. Part I: Atherina suchovi Svitchenska, 1973. Swiss Journal of Palaeontology, 136, $7-18$.

— JAPUNDŽIĆ, S. and BRADIĆ, K. 2017b. Otoliths in situ from Sarmatian (Middle Miocene) fishes of the Paratethys. Part IV: Scorpaenidae, Labridae and Gobiesocidae. Swiss Journal of Palaeontology, 136, 93-109.

— BRATISHKO, A., JAPUNDŽIĆ, S. and BRADIĆ, K. 2017c. Otoliths in situ from Sarmatian (Middle Miocene) fishes of the Paratethys. Part II: Gadidae and Lotidae. Swiss Journal of Palaeontology, 136, 19-44.

— JAPUNDŽIĆ, S. and BRADIĆ, K. 2017d. Otoliths in situ from Sarmatian (Middle Miocene) fishes of the Paratethys. Part V: Bothidae and Soleidae. Swiss Journal of Palaeontology, 136, 109-128.

— AHNELT, H., CARNEVALE, G., JAPUNDZIC, S., BRADIC, K. and BRATISHKO, A. 2017e. Otoliths in situ from Sarmatian (Middle Miocene) fishes of the Paratethys. Part III: Tales from the cradle of the Ponto-Caspian gobies. Swiss Journal of Palaeontology, 136, 45-92.

— BECKETT, H., SCHEIN, J. and FRIEDMAN, M. 2018. Data from: Computed tomography as a tool for linking the skeleton- and otolith-based fossil records of teleost fishes. Dryad Digital Repository. https://doi.org/10.5061/dryad.72rh2

SFERCO, E., LÓPEZ-ARBARELLO, A. and BÁEZ, A. M. 2015. Phylogenetic relationships of $\uparrow$ Luisiella feruglioi (Bordas) and the recognition of a new clade of freshwater teleosts from the Jurassic of Gondwana. BMC Evolutionary Biology, 15, 268.

SHIMADA, K. and FIELITZ, C. 2006. Annotated checklist of fossil fishes from the Smoky Hill Chalk of the Niobrara Chalk (Upper Cretaceous) in Kansas. Bulletin of the New Mexico Museum of Natural History, 35, 193-213.

STARNES, W. C. 1988. Revision, phylogeny and biogeographic comments on the circumtropical marine percoid fish family Priacanthidae. Bulletin of Marine Science, 43, 117-203.

STARON, R. M., GRANDSTAFF, B. S., GALLAGHER, W. B. and GRANDSTAFF, D. E. 2001. REE signatures in vertebrate fossils from Sewell, NJ: implications for location of the KT boundary. Palaios, 16, 255-265.

STEWART, J. D. 1984. Taxonomy, paleoecology, and stratigraphy of the halecostome-inoceramid associations of the North American Upper Cretaceous epicontinental seaways. Unpublished $\mathrm{PhD}$ thesis, University of Kansas, $201 \mathrm{pp}$.

— 1996. Cretaceous acanthomorphs of North America. 383394. In ARRATIA, G. and VIOHL, G. (eds). Mesozoic fishes: systematics and paleoecology. Friedrich Pfeil, Munich, $576 \mathrm{pp}$.

STINTON, F. C. 1957. Fish otoliths from the London Clay of Bognor Regis, Sussex. Proceedings of the Geologists' Association, 67, 15-31.

— 1966. Fish otoliths from the London Clay. 404-464. In CASIER, E. (ed.) Faune ichthyologique du London Clay. Trustees of the British Museum (Natural History), London, $464 \mathrm{pp}$.

— 1973. Fish otoliths from the English Cretaceous. Palaeontology, 16, 293-305.

_ 1977. Fish otoliths from the English Eocene, II. Palaeontographical Society Monographs, 130, 57-126.

— 1978. Fish otoliths from the English Eocene, III. Palaeontographical Society Monographs, 132, 127-189.

— 1980. Fish otoliths from the English Eocene, IV. Palaeontographical Society Monographs, 133, 191-258.

STORMS, R. 1896. Première note sur les poissons wemmeliens (Eocène supérieur) de la Belgique. Bulletin de la Société Belge de Géologie de Paléontologie \& D'Hydrologie, 10, 198-240.

SUGARMAN, P. J., MILleR, K. G., BUKRY, D. and FEIGENSON, M. D. 1995. Uppermost Campanian-Maestrichtian strontium isotopic, biostratigraphic, and sequence stratigraphic framework of the New Jersey Coastal Plain. Geological Society of America Bulletin, 107, 19-37.

SUTTON, M. D. 2008. Tomographic techniques for the study of exceptionally preserved fossils. Proceedings of the Royal Society $B, 275,1587-1593$.

TAVERNE, L. 1989. Crossognathus Pictet, 1858 du Cretacé Inferieur de l'Europe et systematique, paleozoogeographie et biologie des Crossognathiformes nov. ord. (Teleostéens) du Cretacé et du Tertiaire. Palaeontographica Abteilung A, 207, 79-112.

and NOLF, D. 1979. Troisième note sur les poissons des Sables de Lede (Eocène belge): les fossiles autres que les otolithes. Bulletin de la Société Belge de Géologie, 87, 125-152. 
2010. Les Priacanthidae (Teleostei, Perciformes) des Sables de Lede (Eocène moyen, Belgique): ostéologie et otolithes. Bulletin de L'Institut royal des Sciences naturelles de Belgique, Sciences de la Terre, 80, 187-243.

VAN SiMAEYS, S. and STEURBAUT, E. 2006. Belgocaranx luypaertsi gen. and sp. nov., a new skeleton-based carangid fish from the Boom Clay (Rupelian, Early Oligocene) at Kallo (N. Belgium). Bulletin van het Koninklijk Belgisch Instituut Voor Natuurwetenschappen, Aardwetenschappen, 76, 119-130.

TINTORI, A., SUN, Z., NI, P., LOMBARDO, C., JIANG, D. and MOTANI, R. 2015. Oldest stem Teleostei from the late Ladinian (Middle Triassic) of southern China. Rivista Italiana di Paleontologia e Stratigrafia, 121, 285-296.

TRAQUAIR, R. 1911. Les poissons wealdiens de Bernissart. Mémoires du Musée Royal D'Histoire Naturelle de Belgique, 6, $1-65$.

VAN BENEDEN, P. J. 1872. Notice sur un nouve au poisson du terraine laekenien. Bulletins D'Académie Royale de Sciences, des Letters et des Beaux-Arts de Belgique, 2e Série, 34, 420.

VANDENBERGHE, N., VAN SIMAEYS, S., STEURBAUT, E., JAGT, J. W. M. and FELDER, P. J. 2004. Stratigraphic architecture of the Upper Cretaceous and Cenozoic along the southern border of the North Sea Basin in Belgium. Netherlands Journal of Geosciences, 83, 155-171.
WENZ, S. 1965. Les poissons Albiens de Vallentigny (Aube). Annales de Paléontologie, Vertebrates, 51, 1-23.

WOODWARD, A. S. 1895. Catalogue of the fossil fishes in the British Museum (Natural History). Part III. British Museum (Natural History), 544 pp.

1901. Catalogue of the fossil fishes in the British Museum (Natural History). Part IV. British Museum (Natural History), $636 \mathrm{pp}$.

— 1916. The fossil fishes of the English Wealden and Purbeck formations. Part I.. Palaentographical Society Monographs, 79, $1-48$.

— 1918. The fossil fishes of the English Wealden and Purbeck formations. Part II. Palaentographical Society Monographs, 80, 49-104.

1919. The fossil fishes of the English Wealden and Purbeck formations. Part III. Palaentographical Society Monographs, 81, $105-148$.

ZEHREN, S. J. 1979. The comparative osteology and phylogeny of the Beryciformes (Pisces: Teleostei). Evolutionary Monographs, 1, 1-389.

ZHU, M., YU, X., AHLBERG, P. E., CHOO, B., QIAO, T., QU, Q., ZHAO, W., JIA, L., BLOOM, H. and ZHU, Y. 2013. A Silurian placoderm with osteichthyan-like marginal jaw bones. Nature, 502, 188-193. 